\title{
IL-1RT1 signaling antagonizes IL-11 induced STAT3 dependent cardiac and antral stomach tumor development through myeloid cell enrichment
}

\author{
Jon N. Buzzelli, ${ }^{1,2}$ Dan I. Pavlic ${ }^{1}$, Heather V. Chalinor ${ }^{1}$, Louise O'Connor ${ }^{1}$, \\ Trevelyan R. Menheniott ${ }^{1,2}$, Andrew S. Giraud ${ }^{1,2}$, Louise M. Judd ${ }^{1,2}$ \\ ${ }^{1}$ Murdoch Children's Research Institute, Royal Children's Hospital, Parkville, Victoria, 3052 Australia \\ ${ }^{2}$ Department of Paediatrics, University of Melbourne, Royal Children's Hospital, Parkville, Victoria, 3052 Australia \\ Correspondence to: \\ Louise M. Judd, e-mail: louise.judd@mcri.edu.au \\ Keywords: Mucosal immunity, cancer immunobiology, cytokines, IL-1 1, STAT3, IL-1, MDSCS \\ Received: September 24, 2014 \\ Accepted: November 08, 2014 \\ Published: January 06, 2015
}

\section{ABSTRACT}

IL-1 is key driver of gastric tumorigenesis and is a downstream target of IL-11 signaling. Recently, IL-1 cytokines, particularly IL-1 $\beta$, have been flagged as therapeutic targets for gastric cancer treatment. Here, we assess the requirement

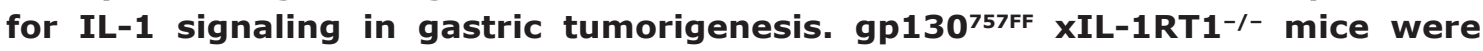
generated to determine the pathological consequence of ablated IL-1 signaling in the IL-11 dependent gp130757FF mouse model of gastric tumorigenesis. Gastric lesions in gp130757FF $\times I L-1 R^{7} 1^{-/-}$mice were increased in incidence and size compared to gp130757F mice. Proximal gastric lesions originated from the cardiac region and were associated with elevated STAT3 activation, loss of specialized gastric cells and a modulated immune response including increased expression of TNF-a and MDSC associated genes. Administration of IL-11 to IL-1RT1 ${ }^{-/-}$mice showed similar changes to gp130757FF XIL-1RT1 $^{-/-}$mice. Spleens from IL-11 treated wildtype mice showed an enrichment of MDSC and gp130757FF $\times I L-1 R T 1^{-/-}$mice had increased MDSCs in the stomach compared to gp130757FF mice. Furthermore, crossing TNF-a ${ }^{-/-}$to gp130757FF mice resulted in reduced lesion size. We conclude that IL-1 signaling antagonizes IL-11/STAT3 mediated pathology and the genetic deletion of IL-1RT1 results in increased tumor burden. We provide evidence that a likely mechanism is due to IL-11/STAT3 dependent enrichment of MDSCs.

\section{INTRODUCTION}

Historically gastric cancers are categorized into 2 main types according to phenotypic and histological characteristics; diffuse carcinomas and intestinal-type gastric cancers (IGC) [1]. IGC develop incrementally after the initial Helicobacter pylori $(H$. pylori) infection and acute inflammation, progressing through chronic inflammation, and metaplasia to neoplasia [2]. IGC occur with persistent $H$. pylori infection, most prominently in the distal gastric antrum and also in the cardia. The cardia is a discrete region of glands distinct from the fundus or body of the stomach, located at the gastro-esophageal junction (GEJ) in humans [3], or the limiting ridge between the squamous esophagus and forestomach in mice [4]. These glands are similar to antral glands in structure, being composed primarily of mucous cells, with other specialized cell types being absent. The normal function of cardiac glands is not well defined, nonetheless recent large scale retrospective population studies in humans have shown that cancers of the gastroesophageal junction are increasing in prevalence [5], and that patients with GEJ cancers have reduced life expectancy compared to those with antral IGC [6].

Numerous cytokines have enhanced expression during chronic $H$. pylori infection and subsequent gastric disease progression, in particular members of the IL-1 and IL-6 families. Elevated levels of these cytokines in the 
absence of other mitigating factors, including $H$. pylori, cause gastric pathology in murine models $[4,7,8]$. Clinical studies have demonstrated a strong correlation between IL-1 $\beta$ polymorphisms and predisposition to gastric cancer development [8-10]. In mice, IL-1 $\beta$ is increased following H. pylori infection [10], and transgenic over-expression of IL- $1 \beta$ using the H/K ATPase promoter caused gastric inflammation and dysplasia [8]. More recently, the Epstein-Barr virus promoter/IL- $1 \beta$ transgenic mouse was shown to develop cardiac and esophageal pathology [4]. The link between IL-1 $\beta$ expression and gastric cancer progression in humans and murine models, has resulted in IL-1 receptor blockade being suggested as a novel therapeutic target in the effort to combat gastric cancer progression $[11,12]$.

IL-1 $\beta$ belongs to a large family of cytokines of which the best characterized are IL- $1 \alpha$, IL- $1 \beta$, IL-18 and IL-33 [13]. IL- $1 \alpha$ and IL-1 $\beta$ bind to their shared receptor, the type 1 IL-1 receptor (IL-1RT1), which subsequently dimerizes with the IL-1R receptor accessory protein (IL-1RAP) resulting in activation of NF-KB [14]. The functions of IL-1 $\alpha$ and IL-1 $\beta$ are similar in many aspects [13], however IL-1 $\alpha$ has the capacity to distinguish between necrosis and atrophy and can be released from damaged cells to promote an immune response [15]. Less is known about the involvement of IL-1 $\alpha$ in gastric cancer progression, however IL- $1 \alpha$ expression is increased in $H$. pylori associated pathology [16] and elevated IL-1 $\alpha$ in gastric tumors has been associated with liver metastasis [17].

The IL-6 family member IL-11 is a pleiotrophic cytokine [7], and has elevated expression in association with gastric cancer development [18, 19]. IL-11 signals via the IL-11R $\alpha / \mathrm{gp} 130$ receptor complex to activate genes involved in proliferation, angiogenesis, inflammation and inhibition of apoptosis $[20,21]$. gp $130^{757 \mathrm{FF}}$ mice contain a knock-in mutation at Y757 of gp130, where a tyrosine has been substituted with phenylalanine, preventing both the phosphatase SHP2 and the negative regulator of STAT3, SOCS3 from binding and consequently resulting in chronic hyper-activation of STAT3 [21]. gp130 $0^{757 F F}$ mice spontaneously develop distal (antral) stomach tumors, which phenocopy chronic H. pylori-induced pathology, particularly the key initiating event, pan-gastritis including an abundance of myeloid derived cells [20,21]. Furthermore, gp $130^{757 \mathrm{FF}}$ pathology is absolutely dependent on IL-11 signaling [19]. IL-11 expression is increased in multiple mouse models of progressive gastric pathology [19], and in human gastric tumors [19, 22]. Additionally, IL-11 causes profound atrophy in the stomach [7], with a prominent downstream target being IL-1 $\beta$ [8].

The aim of our study was to dissect the individual contributions of oncogenic signaling mediated by gp 130 and IL-1RT1 ligands in IL-11/STAT3 mediated gastric cancer development. In addition we evaluated the suitability of IL-1 as novel therapeutic target for gastric cancer. Here we show that IL-1RT1-mediated signaling is dispensable for antral tumor development in the gp $130^{757 F F}$ mouse, as well as IL-11-induced fundic atrophy and metaplasia. In fact, in the absence of IL-1RT1 signaling gastric pathology develops more rapidly and extensively in both the antrum and gastric cardia suggesting that IL-1RT1 signaling may minimize tumor burden by antagonizing IL-11/STAT3 mediated pathology.

\section{RESULTS}

\section{Myeloid-derived immunocytes up-regulate the IL-1 signaling network in the antrum of gp $130^{757 F F}$ mice}

gp $130^{757 F F}$ mice spontaneously develop antral stomach tumors caused by constitutive activation of STAT3 and by 30 weeks of age the antrum of a gp $130^{757 \mathrm{FF}}$ mouse is largely tumor tissue. IL-11 is essential for gp $130^{757 F F}$ induced tumorigenesis $[19,20]$, however the importance of another cytokine, IL-1 $\beta$, and its signaling pathway, has not been quantitatively assessed in this model. IL- $1 \alpha$ and IL-1 $\beta$ expression were increased in 30 week old gp $130^{757 F F}$ mice compared to wildtype littermates, $(65.1 \pm 16.8$ and $15.8 \pm 6.1$ fold respectively; Fig. 1Ai\&ii). The expression of IL-1RT1 and its accessory protein (IL-1RAP) were also increased ( $2.1 \pm 0.4$ and $2.0 \pm 0.3$ fold respectively; Fig. 1Aiii\&iv) as were the IL-1R decoy receptor (IL-1RT2) and the IL-1R antagonist protein (IL-1RAN) $(4.17 \pm 1.1$ and $6.31 \pm 1.7$ fold respectively; Fig. 1 Av\&vi). IL- $1 \beta$ protein was also analyzed by ELISA assay and was increased in the antrum of gp $130^{757 \mathrm{FF}}$ mice compared to WT mice (WT: $3.5 \pm 0.4$, gp130 $7575 \mathrm{FF}: 8.7 \pm 0.6$; Fig. 1B). Together these data suggest that IL-1 signaling may contribute to antral tumor development in gp $130^{757 F F}$ mice.

Activated macrophages have the capacity to secrete pro-inflammatory IL-1 cytokines, and since inflammation is crucial for gp130 $157 \mathrm{FF}$ tumor development [20] we assessed whether activated macrophages contribute to elevated IL-1 $\alpha$ and IL- $1 \beta$ expression in 30 week old gp $130^{757 F F}$ mice. Relative to wildtype mice, gp130 $157 \mathrm{FF}$ stomachs had a large increase in F4/80 positive macrophage infiltrate $(12 \pm 3.7$ fold; Fig. 1C). Peritoneal macrophages extracted from gp $130^{757 F F}$ mice had strongly attenuated IL- $1 \alpha$ and IL-1 $\beta$ mRNA expression compared to wildtype macrophages $(-42.4 \pm 9.4$ and $-10.8 \pm 2.0$ fold respectively; Fig. 1Di\&ii). In wildtype macrophages LPS stimulation increased IL- $1 \alpha$ and IL-1 $\beta$ mRNA expression by $6.5 \pm 1.8$ and $2.4 \pm 0.3$ fold respectively, whilst in stimulated gp $130^{757 \mathrm{FF}}$ macrophages IL- $1 \alpha$ and IL-1 $\beta$ were further increased by $24.1 \pm 5.9$ and $8.5 \pm$ 2.0 fold respectively (Fig. 1Di\&ii). These data suggest that IL-1RT1 ligands contribute to the development of gp $130^{757 F F}$ gastric tumors and that activated macrophages are a potential source of their expression. 

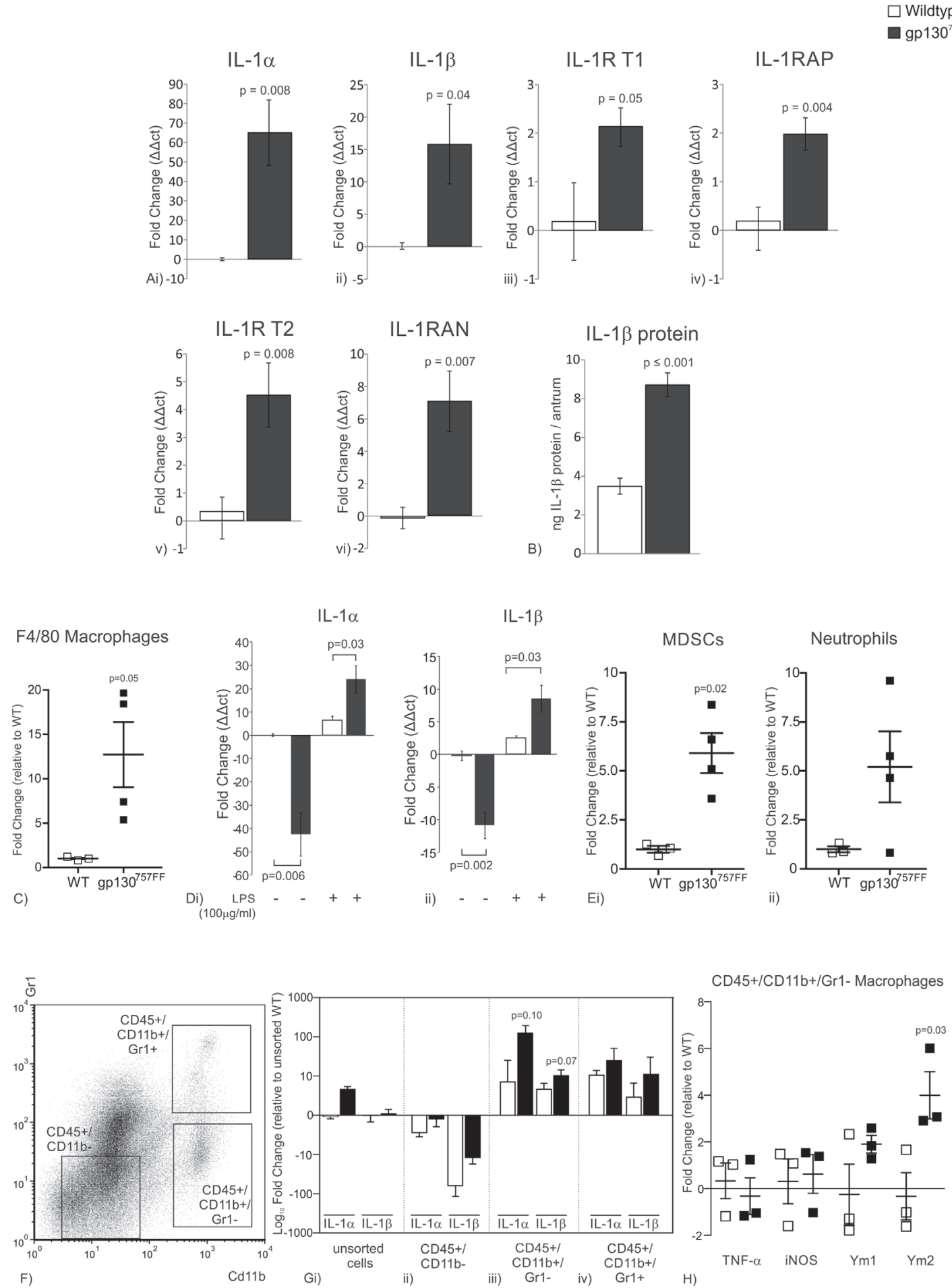

Figure 1: mRNA expression of IL-1RT1 ligands and associated proteins in the distal stomach of 30 week old gp130 $757 \mathrm{FF}$ compared to wildtype mice. (A)(i) IL-1 $\alpha$, (ii) IL-1 $1 \beta$, (iii) IL-1R type 1, (iv) IL-1RAP, (v) IL-1R type 2 and (vi) IL-1RAN. (B) Protein expression of (i) IL-1 $\beta$ in the distal stomach of 30 week old gp130757FF compared to wildtype mice. (C) Proportion of F4/80 macrophages in the stomach of 12 week gp130757F mice compared to wildtype mice. (D) mRNA expression of (i) IL-1 $\alpha$ and (ii) IL-1ßin peritoneal macrophages isolated from either wildtype or gp $130^{757 \mathrm{FF}}$ cultured in the presence or absence of LPS (100ng/ $\mu$ l). (E) Proportion of (i) MDSC and (ii) neutrophils in the stomach of 12 week gp $130^{757 F F}$ mice compared to wildtype mice. (F) Presentation of how CD45 gastric immunocytes were sorted for CD11b and Gr1. (G) mRNA expression of IL-1 $\alpha$ and IL-1 $\beta$ of cell sorted populations; (i) unsorted cells, (ii) $\mathrm{CD} 5^{+} / \mathrm{CD} 11 \mathrm{~b}^{-}$, (iii) $\mathrm{CD} 45^{+} / \mathrm{CD} 1 \mathrm{~b}^{+} / \mathrm{Gr}^{-}$and (iv) $\mathrm{CD} 45^{+} / \mathrm{CD} 1 \mathrm{~b}^{+} / \mathrm{Gr} 1^{+}$. (H) mRNA expression of M1 macrophages markers (TNF- $\alpha$ and iNOS) and $\mathrm{M} 2$ macrophage markers ( $\mathrm{Ym} 1$ and $\mathrm{Ym} 2)$. Bars are means $\pm \mathrm{SEM}, p$-values are presented for statistically significant changes $(p<0.05)$. 
While macrophages likely contribute a significant proportion of the gastric mucosal IL-1 ligand pool, other cellular components, including MDSCs, have been demonstrated to contribute to gastric cancer development and IL-1 cytokine production [8]. We therefore quantified MDSC infiltrate as well as another myeloid-derived immunocyte population, neutrophils, in gp130757FF stomachs compared to wildtype mice (Fig. 1E). Relative to wildtype mice, gp130 $137 \mathrm{FF}$ stomachs had an increase in $\mathrm{CD}_{11} \mathrm{~b}^{+} / \mathrm{Gr}-1^{\mathrm{INT}} \mathrm{MDSC}$ infiltrate $(5.9 \pm 1.0$ fold; Fig. $1 \mathrm{Ei})$ and $\mathrm{CD} 11 \mathrm{~b}^{+} / \mathrm{Gr}-1^{\mathrm{HIGH}}$ neutrophils $(5.2 \pm 1.8$ fold; Fig. 1Eii); however these increases were not as substantial as infiltrating macrophages (Fig. 1C).

To extend our understanding of which immunocyte populations contribute to IL-1 cytokine enrichment in gastric lesions of gp130 $137 \mathrm{FF}$ mice, gastric immunocytes from wildtype $(n=3)$ and gp130 $0^{757 \mathrm{FF}}$ mice $(n=3)$ were sorted. Cell populations collected were as follows (Fig. $1 \mathrm{~F} \& 1 \mathrm{G}$ ): $\mathrm{CD}^{4} 5^{+} / \mathrm{CD} 11 \mathrm{~b}^{-}$cells which are inclusive of $\mathrm{CD}^{+} \mathrm{T}$ cells, $\mathrm{CD} 8^{+} \mathrm{T}$ cells, $\mathrm{B}$ cells and dendritic cells; $\mathrm{CD} 45^{+} / \mathrm{CD} 11 \mathrm{~b}^{+} / \mathrm{Gr}-1^{-}$cells (macrophages); and $\mathrm{CD} 45^{+} /$ $\mathrm{CD}_{11 \mathrm{~b}}{ }^{+} \mathrm{Gr}-1^{+}$cells (Neutrophils and MDSCs). The mRNA expression of IL- $1 \alpha$ and IL- $1 \beta$ was measured in these cells populations by QRT-PCR and compared to wildtype unsorted cells. Unsorted gp130 $0^{757 F F}$ cells had an increase in IL- $1 \alpha$ and IL- $1 \beta$ mRNA expression compared to wildtype controls consistent with findings from whole stomachs (IL- $1 \alpha: 4.7 \pm 0.8$; IL-1 $\beta$ : $0.5 \pm 0.9$; Fig. 1Gi). Relative to unsorted wildtype cells, wildtype $\mathrm{CD}^{2} 5^{+} / \mathrm{CD}_{11} \mathrm{~b}^{-}$cells had reduced IL- $1 \alpha$ and IL-1 $\beta$ mRNA expression by $-3.0 \pm 0.6$ and $-84.3 \pm 36.0$ respectively (Fig. 1Gii). This decrease was consistent in gp $130^{757 \mathrm{FF}} \mathrm{CD} 45^{+} / \mathrm{CD} 11 b^{-}$cells. In gp $130^{757 \mathrm{FF}} \mathrm{CD} 45^{+} /$ CD $11 b^{-}$cells IL- $1 \alpha$ and IL- $1 \beta$ were decreased by $-2.0 \pm$ 0.4 and $-11.5 \pm 1.6$ respectively (Fig. 1Gii). In contrast to isolated $\mathrm{CD} 45^{+} / \mathrm{CD}_{11} \mathrm{~b}^{-}$cells, $\mathrm{CD} 45^{+} / \mathrm{CD} 11 \mathrm{~b}^{+} / \mathrm{Gr}-1^{-}$ cells and $\mathrm{CD} 45^{+} / \mathrm{CD} 11 \mathrm{~b}^{+} / \mathrm{Gr}-1^{+}$cells had enhanced IL- $1 \alpha$ and IL-1 $\beta$ expression (Fig. 1Giii\&iv). Relative to wildtype unsorted cells, wildtype CD $45^{+} / \mathrm{CD} 11 \mathrm{~b}^{+} / \mathrm{Gr}-1^{-}$ cells had an increase in IL- $1 \alpha$ and IL- $1 \beta$ expression by $17.6 \pm 11.7$ and $5.1 \pm 1.5$ fold respectively (Fig. 1Giii). This increase was even greater in gp $130^{757 \mathrm{FF}} \mathrm{CD}^{4} 5^{+}$

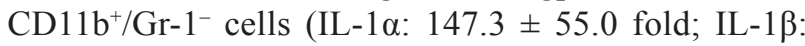
$11.6 \pm 3.9$ fold; Fig. 1Giii). Similarly, wildtype $\mathrm{CD}^{4} 5^{+} /$ $\mathrm{CD}_{11} \mathrm{~b}^{+} / \mathrm{Gr}-1^{+}$cells had an increase in IL- $1 \alpha$ and IL- $1 \beta$ expression by $11.3 \pm 2.6$ and $4.5 \pm 3.8$ compared to unsorted wildtype cells (Fig. 1Giv). Once again this increase was more pronounced in gp130757FF $\mathrm{CD}^{2} 5^{+}$ $\mathrm{CD}_{11} \mathrm{~b}^{+} / \mathrm{Gr}-1^{+}$cells (IL-1 $\alpha$ : $41.1 \pm 27.7$ fold and IL-1 $\beta$ : $25.8 \pm 19.6$ fold; Fig. 1Giv). Considering the large macrophage infiltrate in gp130 $137 \mathrm{FF}$ stomachs we wanted to determine how these macrophages were polarized, therefore $\mathrm{CD} 45^{+} / \mathrm{CD}_{11} \mathrm{~b}^{+} / \mathrm{Gr}-1^{-}$cells (macrophages) were assessed for M1 and M2 markers by QRT-PCR. Relative to wildtype sorted macrophages, gp $130^{757 F F}$ macrophages had no change in the M1 genes TNF- $\alpha$ and iNOS [23] (Fig. $1 \mathrm{H}$ ). In contrast the M2 genes, Ym1 and Ym2 [23], were both increased in gp130 $757 \mathrm{FF}$ macrophages compared to wildtype macrophages by $1.9 \pm 0.4$ and $4.0 \pm$ 1.0 respectively (Fig. $1 \mathrm{H})$. Collectively, these data demonstrate that macrophages are highly abundant in gp $130^{757 F F}$ lesions, express high levels of IL- $1 \alpha$ and IL-1 $\beta$ and therefore are the greatest contributors of IL- $1 \alpha$ and IL- $1 \beta$ enrichment in gp $130^{757 F F}$ gastric lesions. Additionally, MDSCs and neutrophils are also present within gp130 $757 \mathrm{FF}$ gastric lesions and have increased IL- $1 \alpha$ and IL- $1 \beta$ mRNA expression, however not to the extent of macrophages.

We also isolated E-cadherin positive epithelial cells from wildtype and gp $130^{757 \mathrm{FF}}$ mice and assessed IL- $1 \alpha$ and IL-1 $\beta$ mRNA expression however we could not detect a signal for either cytokine (data not shown) suggesting the epithelium does not significantly contribute to increased IL- $1 \alpha$ and IL- $1 \beta$ in gp $130^{757 F F}$ gastric lesions.

\section{The loss of IL-1RT1 increases gp130 ${ }^{757 F F}$ gastric tumor burden}

In order to assess the contribution of IL-1 signaling to tumor burden directly, gp $130^{757 F F}$ mice were crossed with IL-1RT1 $1^{-/}$(receptor utilized by both IL-1 $\alpha$ and IL-1 $\beta$ ) mice. Stomachs were dissected and opened along the lesser curvature (Fig. 2A). As expected gp130 ${ }^{757 \mathrm{FF}}$ mice develop tumor lesions in the antral stomach averaging $44.3 \pm 2.3 \mathrm{~mm}^{2}$. Surprisingly, gp $130^{757 F F}$ xIL-1RT $1^{-/}$mice develop considerably larger antral lesions cumulatively measuring $60.6 \pm 5.6 \mathrm{~mm}^{2}$ (Fig. 2B\&2Cii). This data demonstrates that IL-1 signaling is not required for gp $130^{757 \mathrm{FF}}$ tumorigenesis and that an absence of IL-1 signaling enhances antral tumor growth.

gp $130^{757 \mathrm{FF}}$ xIL-1RT1 $1^{-/}$mice also developed lesions in the proximal stomach which originate from the cardiac glands near the gastro-esophageal junction and will herein be referred to as cardiac lesions (compare Fig. 2Bi and 2Bii). Cardiac lesions were present in $83.3 \%$ of gp $130^{757 F F}$ xIL-1RT1 $1^{-/-}$ mice $[n=12]$ compared to $44.4 \%$ of gp $130^{757 \mathrm{FF}}$ mice $[n=9]$; Fig. 2Cii). When cardiac lesions were present in $g p 130^{757 \mathrm{FF}}$ mice they were considerably smaller than those in gp $130^{757 \mathrm{FF}} \mathrm{xIL}-1 \mathrm{RT} 1^{-/}$mice $\left(5.0 \pm 2.0 \mathrm{~mm}^{2}\right.$ and $12.7 \pm 2.1 \mathrm{~mm}^{2}$ respectively; Fig. 2Cii). Interestingly, cardiac lesions did not influence distal tumor height (Fig. 2Ciii), suggesting that proximal and distal lesions develop independently.

Histological assessment of gp $130^{757 \mathrm{FF}} \mathrm{xIL}-1 \mathrm{RT} 1^{-/}$ stomachs supports a cardiac gland origin for the proximal stomach lesions. In wildtype mice the cardia is typically restricted to a single gland directly adjacent to the forestomach (arrow in Fig. 3Ai\&ii). The cells within this 


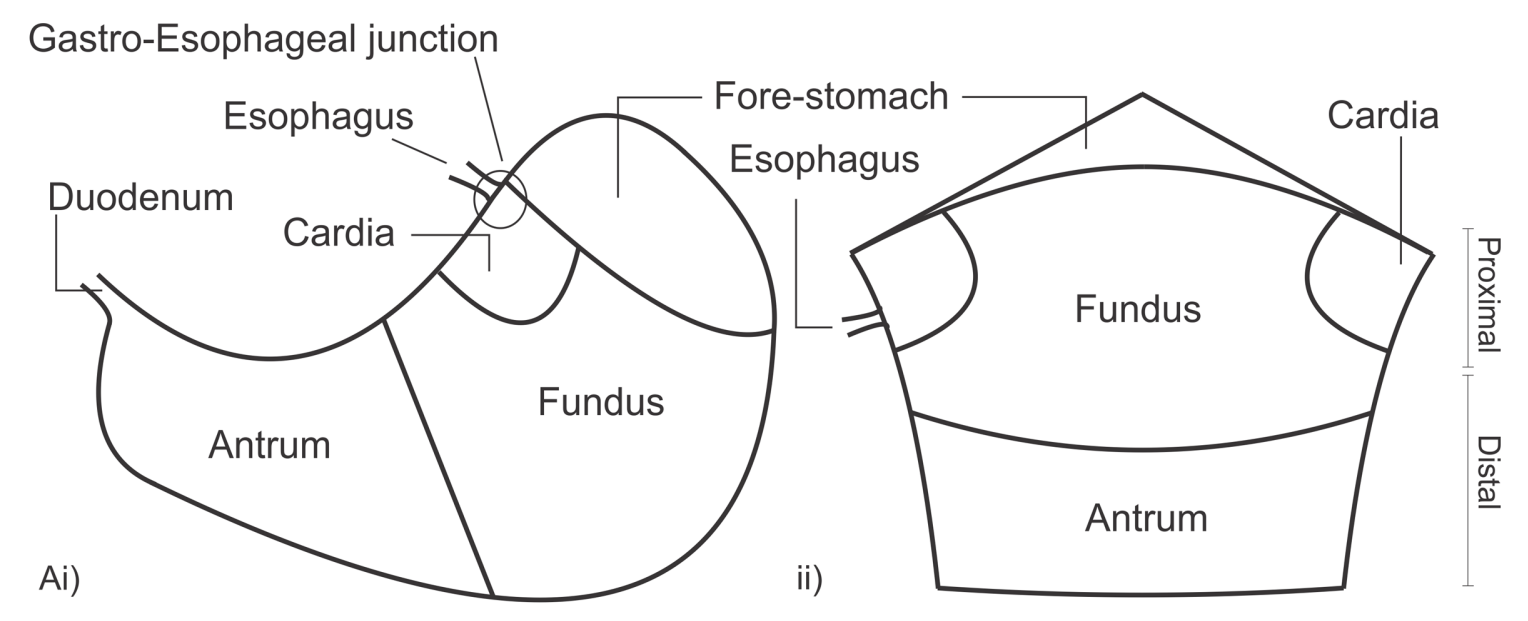

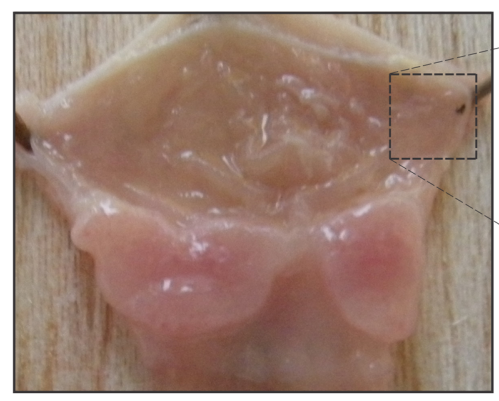

Bi)

gp130 $157 \mathrm{FF}$
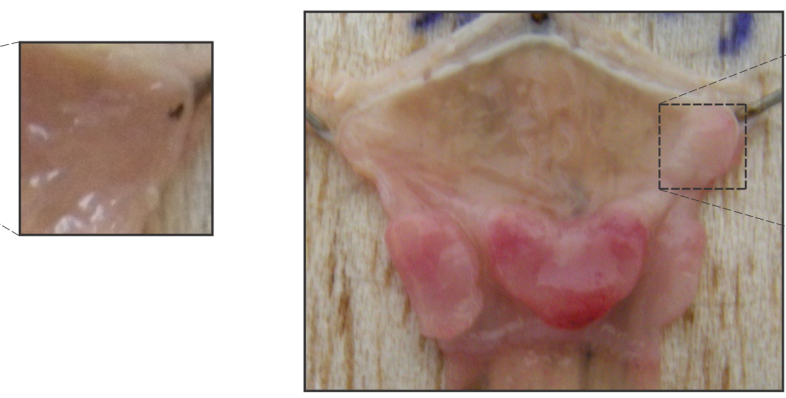

ii) $\quad \mathrm{gp} 130^{757 F F} \times \mathrm{IL}-1 \mathrm{RT} 1^{-1-}$
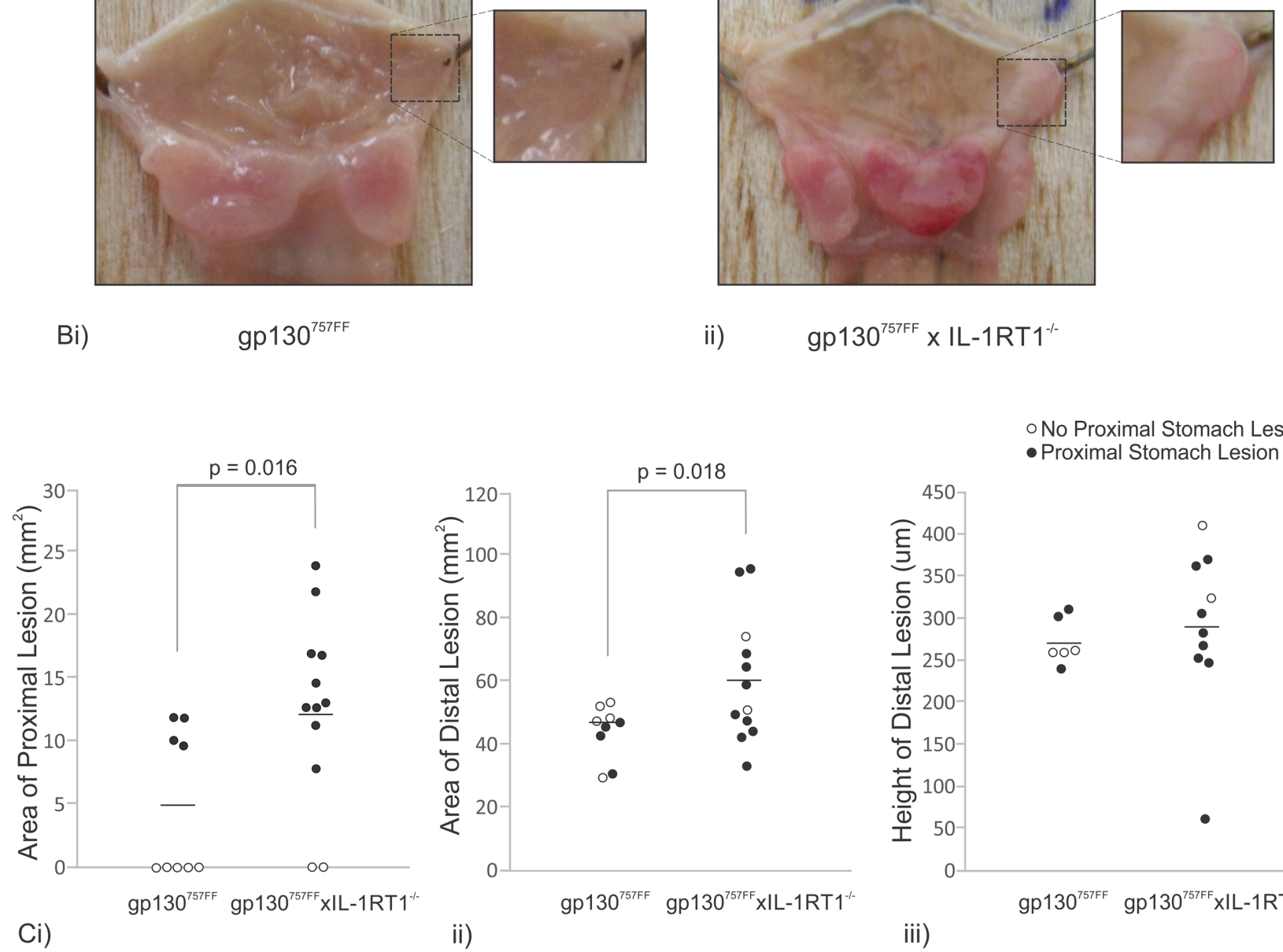

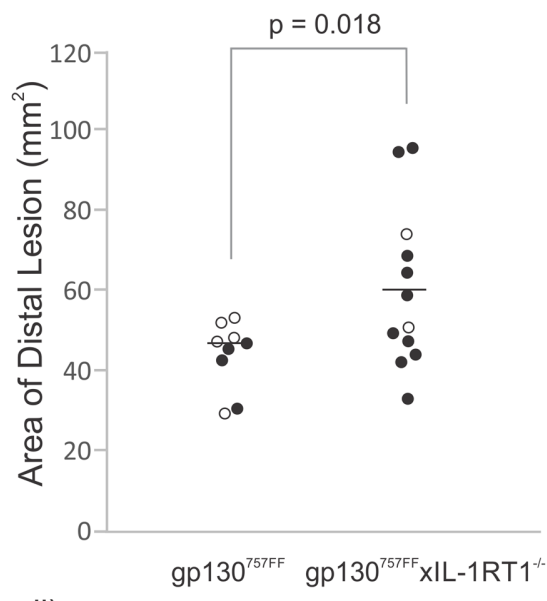

ii) o No Proximal Stomach Lesion

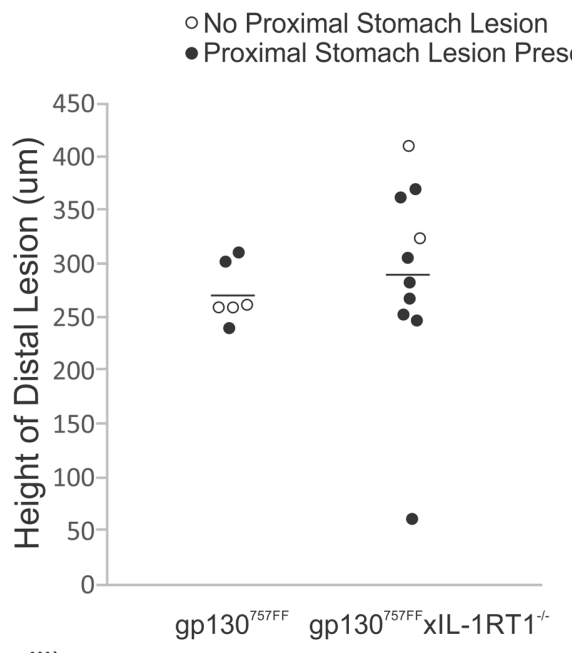

iii)

Figure 2: Macroscopic analysis of pathology in 12 week old gp130 ${ }^{757 F F}$ xIL-1RT1 ${ }^{-/}$mice compared to gp130 ${ }^{757 F F}$ mice. (A) A graphical representation of an intact mouse stomach (i) which has been dissected along the lesser curvature and pinned onto balsa (ii). (B) Macroscopic images of a gp $130^{757 \mathrm{FF}}$ mouse stomach (i) and a gp130757FF $\mathrm{xIL}-1 \mathrm{RT} 1^{-/-}$mouse stomach (ii). (C) Macroscopic analysis of lesion area in the proximal stomach (i) and distal (ii) and microscopic analysis of distal lesion height (iii). $p$-values are presented for statistically significant changes $(p<0.05)$.

gland are cuboidal epithelial cells and resemble the mucous cells of antral glands, reinforced by the presence of acidic carbohydrates evident with Alcian blue staining (Fig. 3A iii). Histologically, parietal, chief and mucous neck cells are absent from the cardiac glands. Examination of the proximal stomach from a gp130757FF $\mathrm{xIL} 1 \mathrm{RT} 1^{-/-}$ mouse demonstrates that the most significantly affected glands are the cardiac glands adjacent to the forestomach. 

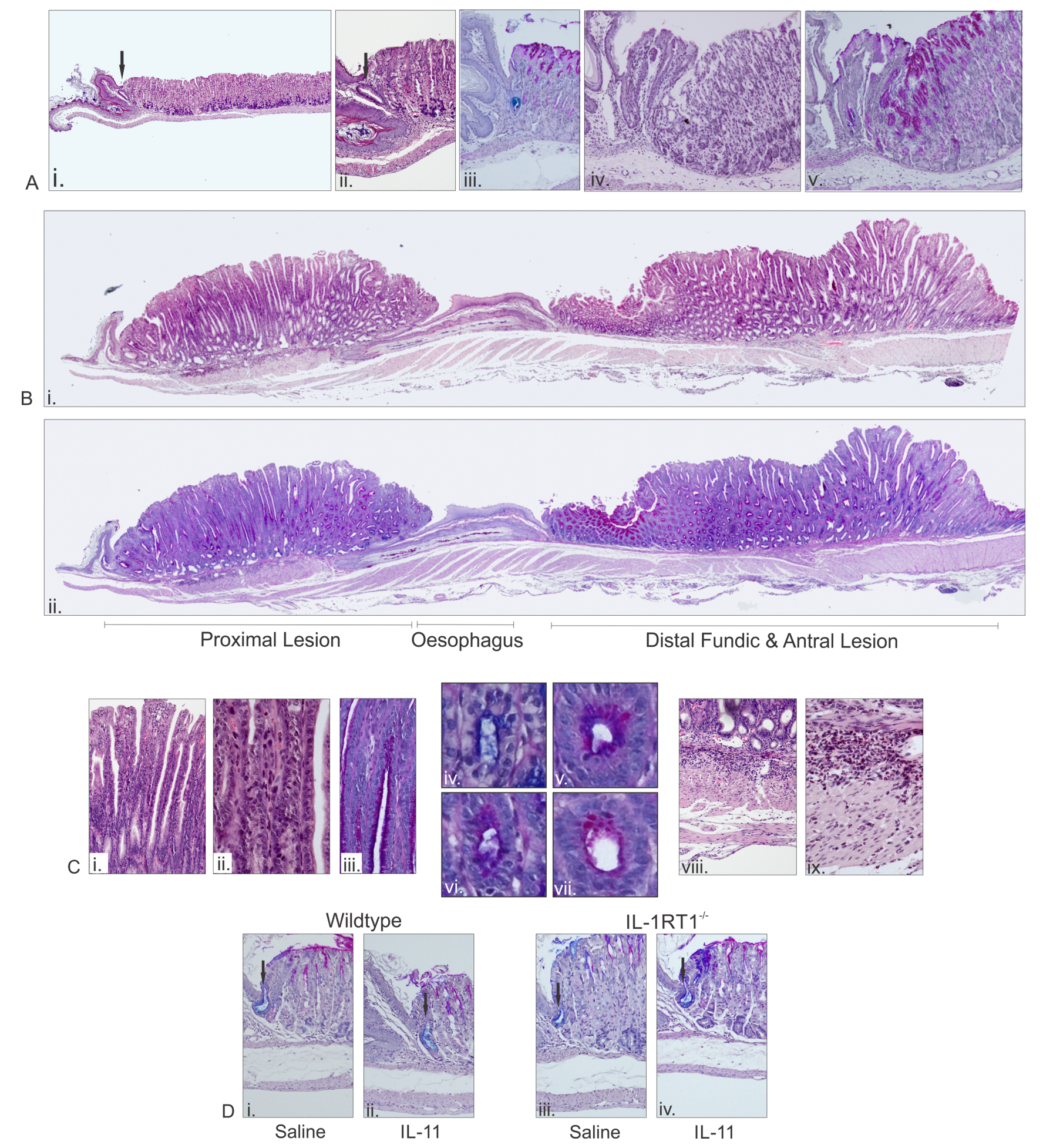

Figure 3: Microscopic analysis of pathology in 12 week old gp130 ${ }^{757 F F} \mathrm{xIL} 1 \mathrm{RT} 1^{-/-}$mice and in WT and IL-1RT1 ${ }^{-/-}$mice administered with IL-11 for 7 days. (A) H\&E landscape of a wildtype proximal stomach (Fundus/Cardia) (i), normal cardia H\&E (ii), and AB-PAS (iii). A developing lesion in the gp $130^{757 \mathrm{FF}} \mathrm{xIL}-1 \mathrm{RT} 1^{-/}$cardia regions H\&E (iv) and AB-PAS (v). (B) A pronounced lesion in the gp130757FF $x_{I L-1 R T 1^{-/}}$stomach H\&E (i) and AB-PAS (ii). (C) Glandular structure gp130757FF XIL-1RT1 $^{-/-}$stomach (H\&E; i\&ii, AB-PAS; iii-vi) and associated submucosal infiltrate (H\&E; viii\&ix). (D) Characteristic cardia in WT mice treated with saline (i) or IL-11 (ii) and in IL-1 RT1 ${ }^{-/-}$mice treated with saline (iii) or IL-11 (iv). Arrows in images indicate cardiac glands. 
These cardiac glands expand and become hyperplastic with associated inflammatory cells. Directly adjacent to the abnormal cardia are normal fundic glands (Fig. 3Aiv\&v). With larger cardiac lesions the origin of the lesion is no longer as apparent since the entire proximal stomach is affected and proximal lesions become continuous with distal lesions (Fig. 3Bi\&ii). Characteristics of the proximal lesions include near complete atrophy, foveolar hyperplasia and some dysplasia (Fig. 3Ci-iii), accompanied by a mix of mucous cells (Fig. 3Civ-vii) and moderate inflammation (Fig. 3Cviii\&ix).

Previously, in a study assessing the effects of maximal gp130/STAT3 activation on the gastric mucosa, we reported that systemically administered IL-11 $(20 \mu \mathrm{g} /$ day) caused gastric atrophy and mucus metaplasia through STAT3 activation, and coincident with elevated IL-1 $\beta$ expression [7]. Others have shown that overexpression of IL-1 $\beta$ in the mouse stomach results in tumor induction $[4,8]$. Here we administered a significantly lower and more physiologically relevant dose of IL-11 (1 $\mu \mathrm{g} /$ day) to wildtype and IL-1RT1 ${ }^{-/-}$mice to determine if IL-1RT1 signaling was required for IL-11 induced changes to the gastric mucosa. Histological assessment of the cardiac and fundic glands following administration of low concentrations of IL-11 demonstrated no obvious changes in either wildtype or IL-1RT1 $1^{-/-}$mice (Fig. 3D). Normal cardiac glands stained positive for acidic mucins are indicated in each image (Fig. 3Di-iv).

\section{IL-11/STAT3 mediates the development of gp130 $^{757 F F} \times$ IL-1RT1 ${ }^{-/}$cardiac lesions}

Antral tumor development in gp130757FF mice is caused by IL-11-dependent hyperactivation of STAT3 [19], so we tested whether the cardiac stomach lesions of gp $130^{757 \mathrm{FF}} \mathrm{xIL}-1 \mathrm{RT}^{-/}$mice also developed as a result of IL-11-induced STAT3 phosphorylation (pSTAT3). pSTAT3/STAT3 in the proximal stomach was elevated in IL-1RT1 $1^{-/}$, gp $130^{757 F F}$ and gp $130^{757 F F} \times I L-1 R T 1^{-/}$mice compared to wildtype controls $(1.8 \pm 0.2,4.6 \pm 0.7$ and $5.8 \pm 1.1$ fold respectively; Fig. 4Ai). Cardiac lesions of gp130 ${ }^{757 F F}$ xIL-1RT1 ${ }^{-/-}$mice also had a marked increase in STAT3 phosphorylation compared to all other groups suggesting excess STAT3 activation drives cardiac lesion development (12.2 \pm 1.3 ; Fig. 4Ai). Activation of the gp130 complex can additionally induce three alternative transcriptional factors, STAT1, EKR1/2 and AKT, through phosphorylation events [24]. We quantified these signaling molecules in the proximal stomach of gp130 $157 \mathrm{FF}$ xIL-1RT1 ${ }^{-/}$mice. No activation of STAT1 was observed for any group, whilst the ratio of ERK1/2 and AKT phosphorylation to total protein was not statistically different between groups (Fig. 4Aii\&iii), further highlighting STAT3 activation as the driver of cardiac lesion development. To determine the gp130 ligand required for STAT3 activation within the cardiac lesions we measured IL-6 and IL-11 mRNA expression, as well as the IL-11 protein. IL-6 mRNA expression was increased in the cardiac lesions of gp $130^{757 \mathrm{FF}} \mathrm{xIL}-1 \mathrm{RT} 1^{-/-}$mice $(2.9$ \pm 1.3 fold) however, it was not different to unaffected proximal stomach from gp $130^{757 F F} \times I L-1 R T 1^{-/}$mice (Fig. 4B). IL-11 mRNA expression was significantly increased 3.2 fold in the gp $130^{757 \mathrm{FF}} \mathrm{xIL}-1 \mathrm{RT}^{-/}$cardiac lesions compared to wildtype and unaffected gp $130^{757 F F}$ xIL$1 \mathrm{RT}^{-/}{ }^{--}$tissue (Fig. 4Ci). Relative to $\beta$-actin, IL-11 protein was also increased in the gp $130^{757 \mathrm{FF}} \mathrm{xIL}-1 \mathrm{RT} 1^{-1}$ cardiac lesions (1.87 \pm 0.22 fold) compared to wildtype and unaffected gp130757FF $x I L-1 \mathrm{RT}^{-/-}$tissue (Fig. 4Cii). We also attempted to determine IL-6 protein levels however were unable to detect IL- 6 protein in the fundic or cardiac gastric mucosa of any group using three different IL-6 specific antibodies (sc-1265, Santa Cruz; MP5-20F3, BD Biosciences; MP5-32C11, BD Biosciences). These data suggest that IL-11 but not IL-6 induced STAT3 activation promotes the development of cardiac lesions, a pathological outcome which is more frequent with ablated IL-1 signaling.

\section{IL-1RT1 signaling does not affect IL-11 signaling in the stomach}

To determine the requirement of IL-1 signaling for the pathological effects of IL-11 following its systemic administration, we measured the pSTAT3/STAT3 ratio in the proximal stomach of mice treated with $1 \mu \mathrm{g}$ IL-11/ day delivered by mini-osmotic pumps (MOPs). Wildtype $(1.62 \pm 0.20$ fold $)$ and IL-1RT1 ${ }^{-/-}$mice $(1.54 \pm 0.11$ fold $)$ had similar increases in STAT3 phosphorylation following IL-11 administration, suggesting that IL-1 signaling is not required for IL-11 signaling in the stomach (Fig. 4Di). We also tested the activation of STAT1, ERK1/2 and AKT. STAT1 activation could not be detected in any group, and the ratio of ERK1/2 and AKT phosphorylation compared to total protein was not altered (4Dii\&iii). As IL-11 administration may promote endogenous expression of gp130 ligands, thereby confounding its effects, we measured the mRNA expression of endogenous gastric IL-6 and IL-11. IL-6 was decreased in IL-11 treated IL$1 \mathrm{RT} 1^{-/-}$mice compared to IL-11 treated wildtype mice $(-3.5 \pm 1.0$ fold; Fig. 4E). The expression of IL-11 was not changed in IL-11 treated wildtype or IL-1RT1 $1^{-/-}$mice (Fig. $4 \mathrm{~F})$. These data show that the loss of IL-1 signaling does not influence IL-11-mediated STAT3 activation. However, consistent with previous reports [4], IL-1RT1 signaling is required for IL-6 expression during STAT3 induced gastric atrophy.

Proximal stomach lesions show transmural inflammation associated with precancerous changes (Fig. 3C) and elevated STAT3 activation with increased IL-11 expression (Fig. 4). We therefore investigated genes 

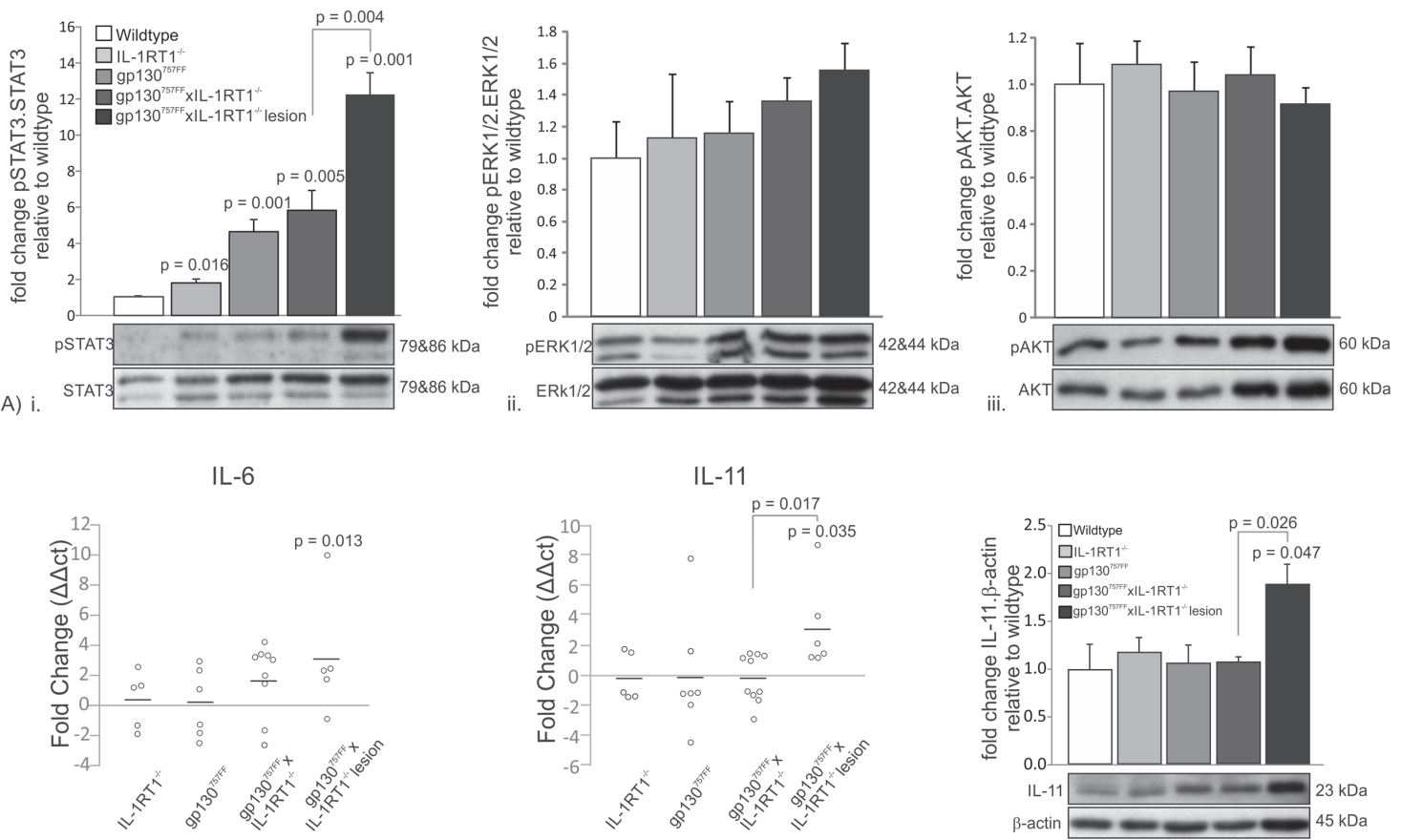

B)

C)i.

ii.
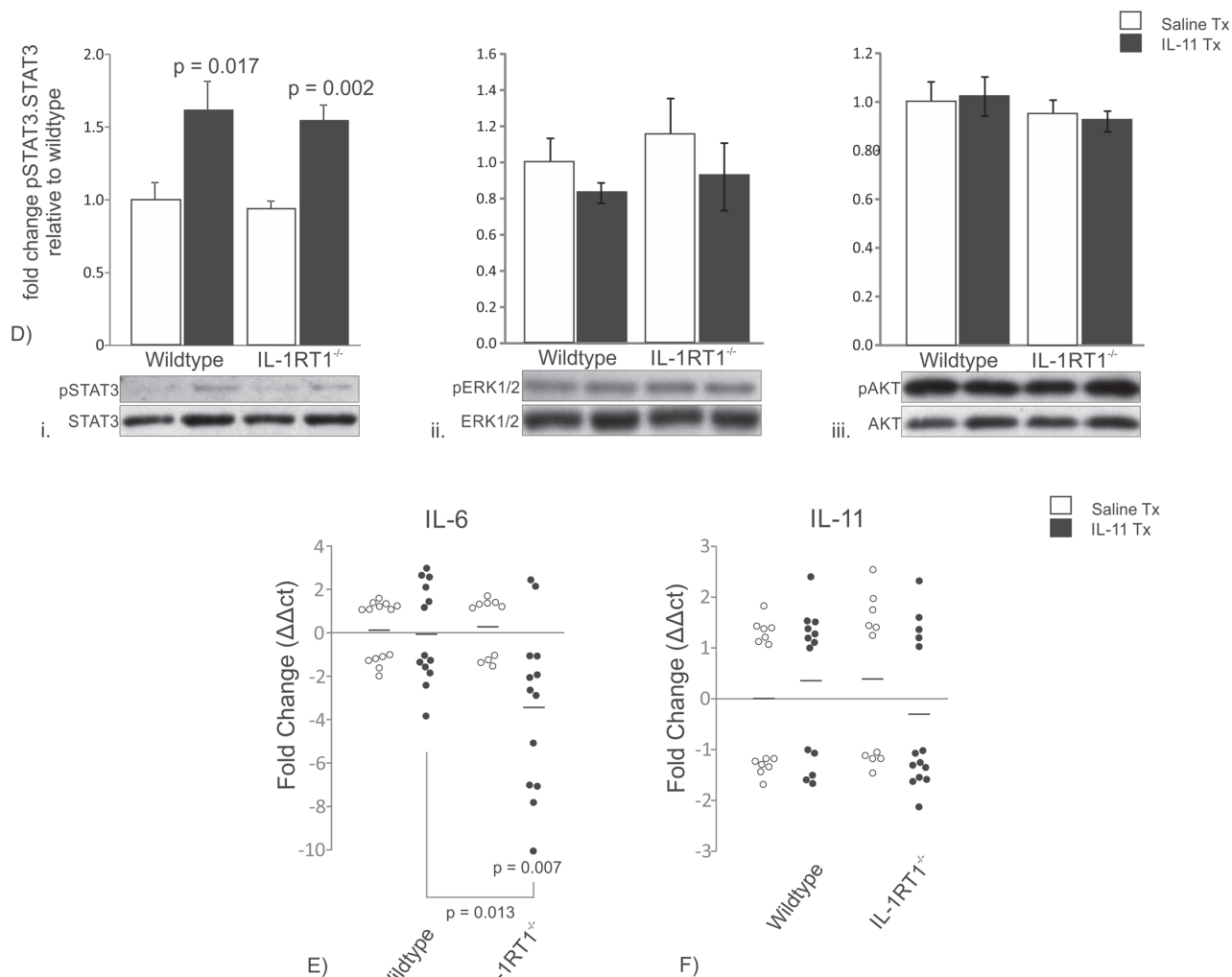

Figure 4: Proximal stomach signaling mechanisms in 12 week old gp130 ${ }^{757 F F}$ xIL-1RT1 ${ }^{-/}$mice and, wildtype and IL-1RT1 ${ }^{-/}$mice administered 1ug of IL-11 daily for 7 days. gp130 ${ }^{757 F F}$ mice develop gastric pathology because of hyperactivation of STAT3; therefore the expression of gp130 ligands and activations of downstream transcription factors were analyzed. (A) Immunoblot analysis of STAT3, ERK1/2 and AKT phosphorylation in 12 week old gp $130^{757 F F} \times \mathrm{IL}^{-1} \mathrm{RT}^{-1-}$ mice and expression of (B) IL-6 mRNA and (C) IL-11 (i) mRNA and protein (ii). (D) Immunoblot analysis of STAT3, ERK1/2 and AKT phosphorylation in wildtype and IL-1RT1 ${ }^{-/}$mice administered $1 \mu \mathrm{g}$ of IL-11 for 7 days and mRNA expression of (E) IL-6, and (F) IL-11. Bars are means \pm SEM, $p$-values are presented for statistically significant changes $(p<0.05)$. 
involved in immune regulation and epithelial homeostasis. Relative to wildtype, DMBT1 [25] expression was increased in gp130 $137 \mathrm{FF}$ proximal stomach $(3.3 \pm 1.0$ fold $)$, unaffected gp130 $0^{\mathrm{FF}} \mathrm{xIL}-1 \mathrm{RT} 1^{-/-}$proximal stomach $(2.8 \pm$ 0.3 fold) and to a much greater extent in $\mathrm{gp} 130^{\mathrm{FF}} \mathrm{xIL}-1 \mathrm{RT} 1^{-/}$ cardiac stomach lesions (34.7 \pm 9.0 fold; Supp Fig. 1). Similarly RegIII $\beta$ [26] was increased 5.1 $\pm 1.7,19.7 \pm$ 11.3 and $575.0 \pm 96.1$ fold respectively (Supp Fig. 1). Conversely, GKN1 and GKN2 [27] were decreased in gp $130^{\mathrm{FF}} \mathrm{xIL} 1 \mathrm{RT}^{-/-}$cardiac stomach lesions $5.6 \pm 1.2$ and $4.9 \pm 0.9$ fold respectively (Supp Fig. 1). DMBT1 mRNA expression was increased in IL-11 treated WT and IL$1 \mathrm{RT}^{-/-}$mice $(4.4 \pm 1.2$ fold $2.8 \pm 0.6$ fold; Supp Fig. 1), whilst RegIII $\beta$ was not altered (Supp Fig. 1). GKN1 and GKN2 mRNA expression were decreased in IL-11 treated IL-1RT1 ${ }^{-1-}$ mice $(-1.3 \pm 0.2$ fold $)$, but not IL-11 treated WT mice (Supp Fig. 1). These data suggests that the development of cardiac stomach lesions is associated with enhanced DMBT1 and RegIII $\beta$ and suppressed GKN1\&2 mRNA expression. In addition these effects are potentiated by IL-11 in the absence of IL-1RT1 signaling, underscoring the crucial role played by IL-11 in gastric tumorigenesis.

\section{gp130 $^{757 \mathrm{FF}} \times \mathrm{xIL}^{-1 \mathrm{RT} 1^{-/}}$cardiac lesions show a loss of differentiated gastric cell markers}

Since gp130 $137 \mathrm{FF}$ xIL-1RT1 $1^{-/-}$cardiac lesions showed extensive atrophic changes we compared the loss of specialized gastric cell types by assessing mRNA expression markers of differentiated fundic cell populations. gp130757FF $\mathrm{xIL}-1 \mathrm{RT} 1^{-/}$cardiac lesions showed a significant reduction in mRNA expression of markers for parietal cells (H/K ATPase $\alpha, H / K$ ATPase $\beta$ \& CCKBR), chief cells (Mist1), surface mucous cells (Muc5AC) and progenitor cells (BMP4\&Lgr5; Supp Fig. 2). The metaplastic SPEM lineage (TFF2) was also reduced in gp $130^{757 F F} \times I L-1 R T 1^{-/-}$cardiac lesions however not significantly (Supp Fig. 2). Administration of low dose IL-11 to wildtype mice did not alter the expression of proximal stomach gastric cell markers, however IL-11 treatment of IL-1RT1 $1^{-/}$mice led to reduced expression of markers of differentiation in a similar pattern to gp $130^{757 F F}$ xIL-1RT1 ${ }^{-/}$mice (Supp Fig. 2). This data supports previous findings which demonstrate IL-11 to induce gastric atrophy [7], a process which appears to be accelerated in the absence of IL-1RT1 signaling as demonstrated by a decrease of mRNA markers of gastric epithelial cells (Supp Fig. 2).

\section{Systemic administration of IL-11 causes an enrichment of MDSCs}

Systemic IL-11 administration caused marked changes to splenic cell populations (Fig. 5A). CD11b ${ }^{+}$ Gr- $1^{\text {INT }}$ MDSCs were enriched in wildtype mice treated with IL-11 (WT-control: $1.0 \pm 0.04$ fold; WT-IL11: $1.4 \pm 0.13$ fold) but this did not occur in the absence of IL-1 signaling (IL-1RT1-control: $1.03 \pm 0.06$; IL1RT1-IL-11:1.05 \pm 0.08; Fig. 5Ai). Conversely, IL-11 administration resulted in a reduction in $\mathrm{CD}^{+} \mathrm{T}$ cells (WT-control: $1.0 \pm 0.04$ fold; WT-IL11: $0.86 \pm 0.03$ fold) and $\mathrm{CD}^{+} \mathrm{T}$ cells (WT-control: $1.0 \pm 0.03$ fold; WTIL11: $0.86 \pm 0.03$ fold) in wildtype mice (Fig. 5Aii\&iii). Interestingly, basal (no treatment) IL-1RT1 $1^{-/}$mice had an increase in $\mathrm{CD}^{+} \mathrm{T}$ cells (WT-control: $1.0 \pm 0.04$; IL1RT1-control: $1.14 \pm 0.04$ ) and $\mathrm{CD}^{+} \mathrm{T}$ cells (WT-control: $1.0 \pm 0.03$; IL-1RT1-control: $1.13 \pm 0.06)$ compared to wildtype mice, however they showed a similar reduction in $\mathrm{CD}^{+} \mathrm{T}$ cells (IL-1RT1-control: $1.14 \pm 0.04$; IL-1RT1IL11: $0.095 \pm 0.03$ ) and $\mathrm{CD}^{+} \mathrm{T}$ cells (IL-1RT1-control: $1.0 \pm 0.03$; IL-1RT1-IL11: $0.096 \pm 0.04)$ following IL-11 treatment (Fig. 5Aii\&iii). Furthermore, the basal mRNA expression of S100A8 and S100A9, established markers of MDSC activity, were increased in the spleen of IL-1RT1 $1^{-/}$ mice compared to WT mice $(3.6 \pm 0.3$ and $3.4 \pm 0.2$ fold respectively; Fig. 5Bi\&ii). Following IL-11 administration wildtype mice showed an increase in mRNA expression of S100A8 and S100A9, being $2.1 \pm 0.3$ and $2.4 \pm 0.4$ fold respectively (Fig. 5Bi\&ii). The basal increase of S100A8 and S100A9 in IL-1RT1 ${ }^{-/}$mice compared to wildtype controls was not affected by IL-11 administration (Fig. 5Bi\&ii). Other MDSC associated genes including MIP2 and Arg-1 were also tested, however they were unchanged between groups (data not shown). In contrast, there were no differences in splenic immunocyte populations between gp130 $137 \mathrm{FF}$ mice and gp130 $157 \mathrm{FF}$ xIL-1RT1 ${ }^{-/-}$mice (Fig. 5C). These data show that systemic IL-11 enhances MDSC enrichment in the spleen whilst reducing $\mathrm{CD}^{+}$and $\mathrm{CD}^{+}$ $\mathrm{T}$ cells. Furthermore, absence of IL-1 signaling confers heightened activity of MDSC cells, evident by an increase in S100A8 and S100A9 mRNA expression, and mimicked by the administration of IL-11 to wildtype mice.

\section{MDSCs are enriched in the stomach of gp130 ${ }^{757 F F}$ xIL-1RT1 $^{-/}$mice compared to gp130 ${ }^{757 F F}$ mice}

Gastric tumors are inflammatory in nature therefore we assessed the abundance of the myeloid and $\mathrm{T}$ cell populations in the stomachs of gp $130^{757 \mathrm{FF}}$ xIL-1RT1 ${ }^{-/}$mice compared to gp $130^{757 F F}$ mice (Fig. 6A). Relative to gp $130^{757 \mathrm{FF}}$ mice, gp $130^{757 \mathrm{FF}} \mathrm{xIL}-1 \mathrm{RT} 1^{-/}$ mice had an increase in gastric CD $11 b^{+} / \mathrm{Gr}-1^{\mathrm{INT}}$ MDSCs (gp130 $157 \mathrm{FF}: 1.0 \pm 0.12$; gp130 ${ }^{757 \mathrm{FF}}$ xIL-1RT1 $1^{-/}: 1.6 \pm$ $0.13)$ and a decrease in neutrophils (gp130 ${ }^{757 \mathrm{FF}}: 1.0 \pm$ 0.22; gp $130^{757 F F} \times I L-1 R T 1^{-/}: 0.25 \pm 0.13$; Fig. 6Ai\&ii). F4/80 macrophages, $\mathrm{CD}^{+} \mathrm{T}$ cells and $\mathrm{CD}^{+} \mathrm{T}$ cells were not changed between groups (Fig. 6Aiii-v). These data suggest that increased MDSC infiltrate and deceased neutrophil infiltrate in the stomach of gp $130^{757 \mathrm{FF}}$ 
MDSCs

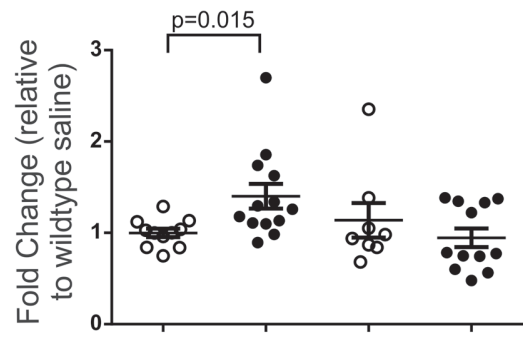

Ai)
Wildtype IL-1RT1 $1^{-/}$

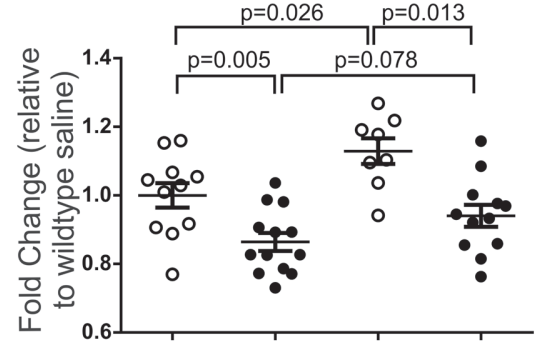

ii)
CD4 ${ }^{+} \mathrm{T}$ cells

Wildtype
IL-1RT $1^{-1-}$

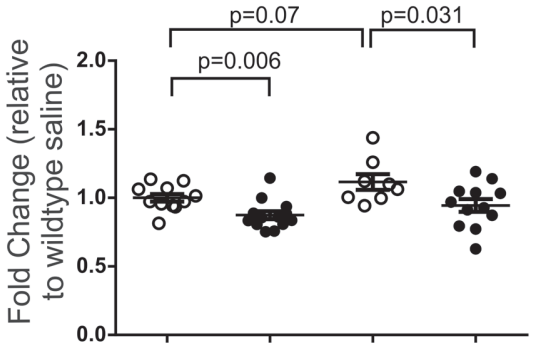

iii) Wildtype IL-1RT1
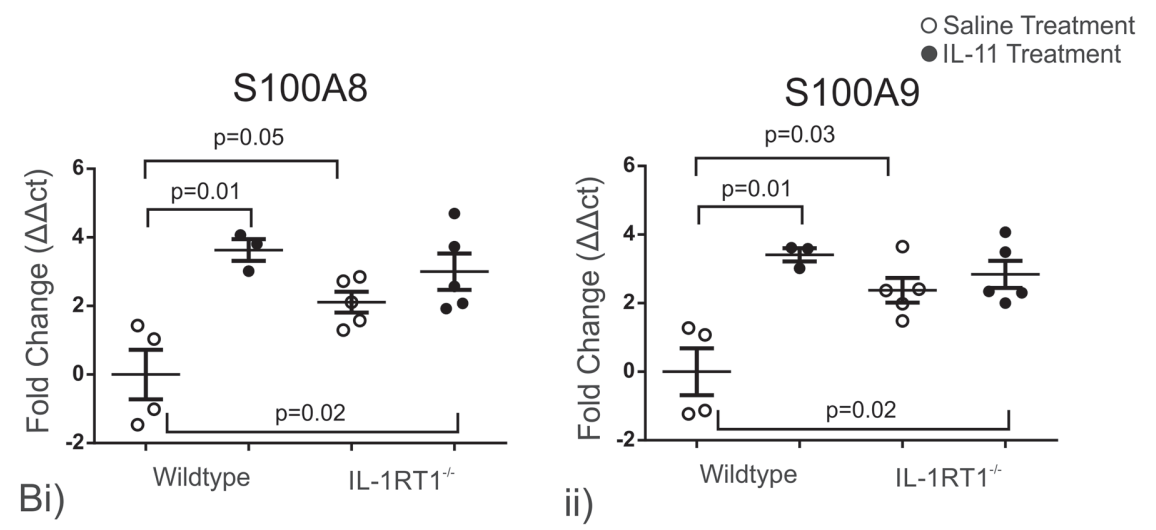

ii)

$\square$ gp $130^{757 F F}$
$\square$ gp $130^{757 F F}$ xIL-1RT1 ${ }^{-/}$

MDSCs
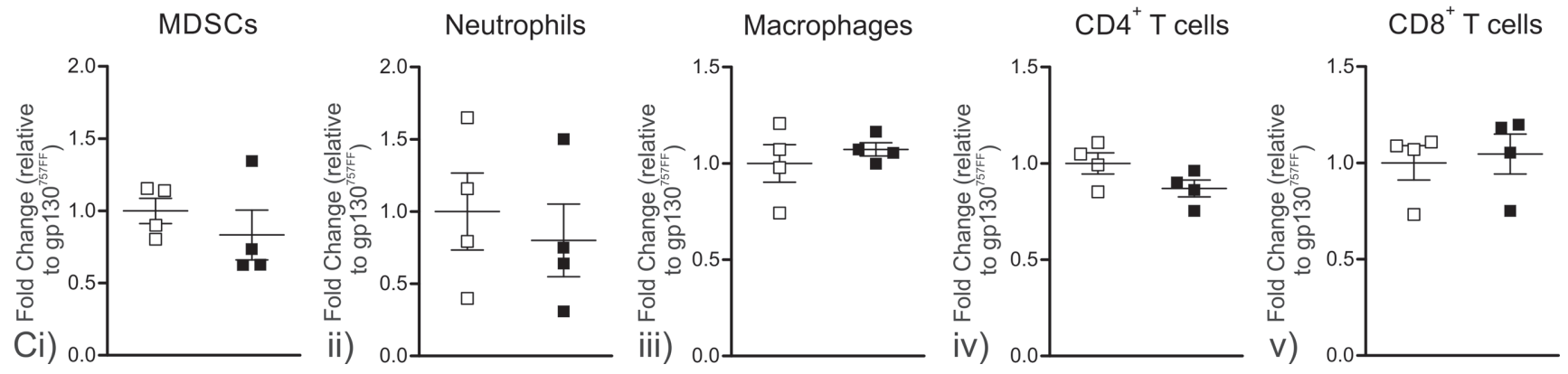

Figure 5: (A) Cell populations in wildtype and IL-1RT1 $1^{-/}$mice constitutively administered $1 \mu \mathrm{g}$ IL-11 daily for 7 days; (i) MDSC, (ii) CD4 T cells and (iii) CD8 T cells. (B) mRNA expression changes of genes expressed by MDSCs analyzed via QRT-PCR in the spleens of wildtype and IL-1RT1 ${ }^{-/}$mice constitutively administered $1 \mu \mathrm{g}$ IL-11 daily for 7 days (i) S100A8 \& (ii) S100A9. (C) Spleen immune cell populations in gp130 $757 \mathrm{FF} \times \mathrm{XIL}-1 \mathrm{RT} 1^{-/}$mice compared to gp130 $157 \mathrm{FF}$ mice; (i) MDSCs, (ii) Neutrophils, (iii) Macrophages, (iv) CD4 ${ }^{+} \mathrm{T}$ cells and (v) CD8 ${ }^{+} \mathrm{T}$ cells. Bars are means \pm SEM, $p$-values are presented for statistically significant changes $(p<0.05)$.

$\mathrm{xIL}-1 \mathrm{RT} 1^{-/-}$mice exacerbates gastric pathology in these mice compared to gp $130^{757 \mathrm{FF}}$ mice.

gp $130^{757 F F}$ mice have increased gastric IL- $1 \alpha$ and IL-1 $\beta$ mRNA expression. In gp $130^{757 F F} \mathrm{xIL}-1 \mathrm{RT} 1^{-1-}$ mice, IL- $1 \alpha$ was increased by $3.5 \pm 0.7$ fold in the unaffected proximal stomach and by $27.2 \pm 7.7$ fold in cardiac lesions (Fig. 6Bi). In contrast, IL-1 $\beta$ mRNA expression was unchanged (Fig. 6Bii). Considering gastric tumors of gp $130^{757 \mathrm{FF}}$ mice are associated with increased prevalence of myeloid cells (Fig. 1C\&1E), we measured the mRNA expression of MIP2, TNF- $\alpha$, IL-23 and amphiregulin; four cytokines known to be expressed by myeloid-derived cells. 

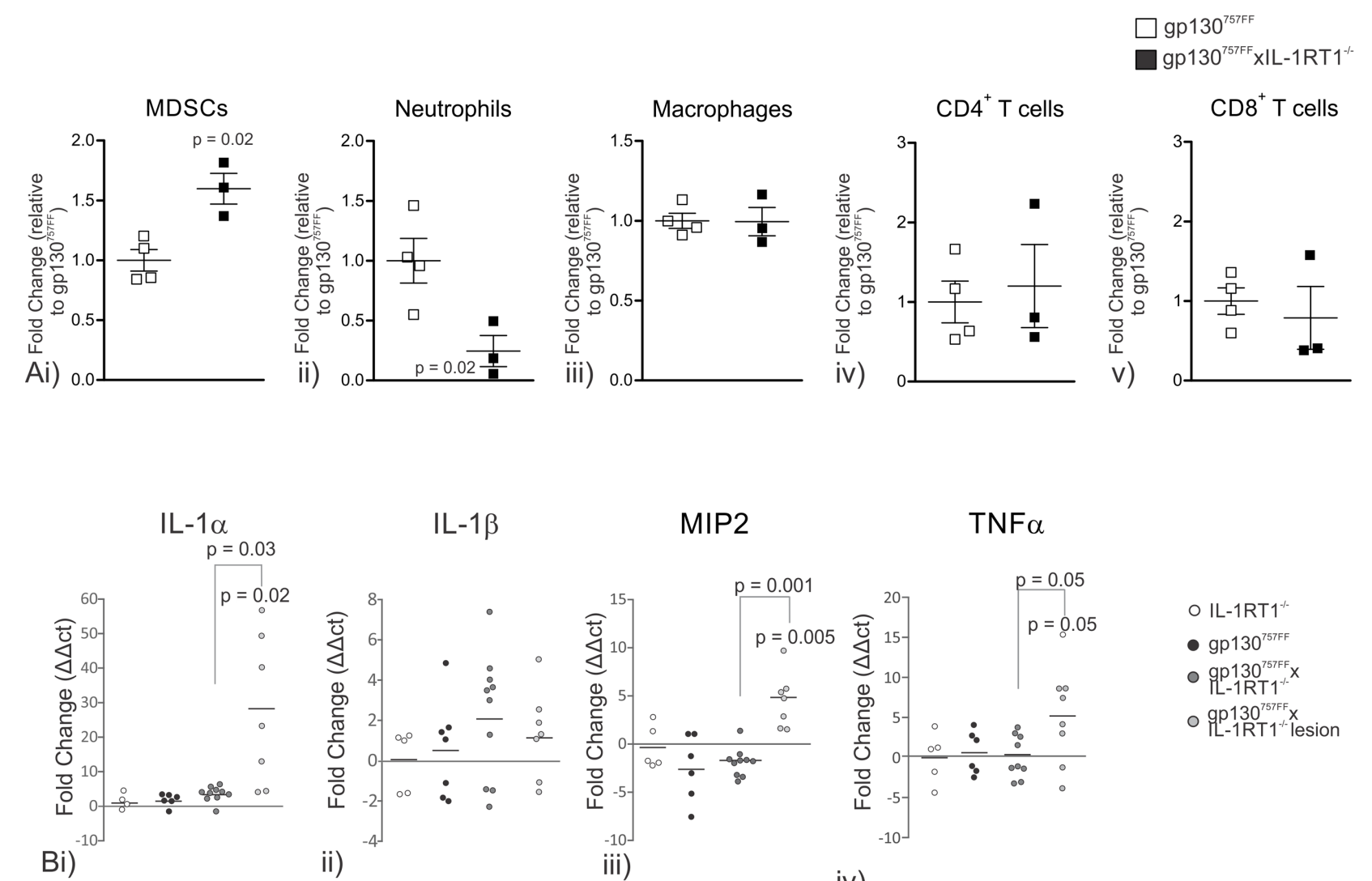

TNF $\alpha$
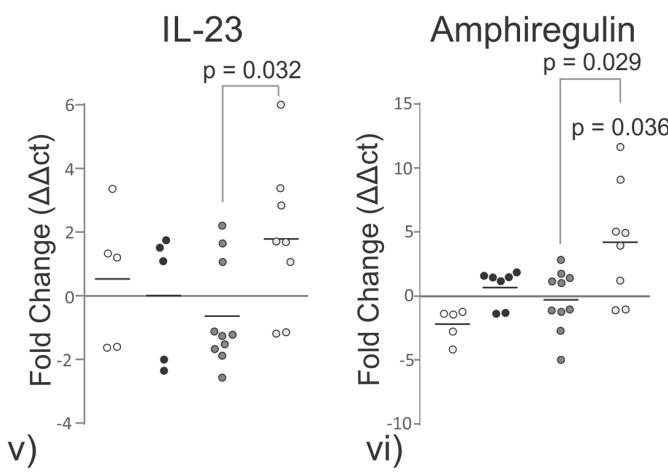

iii)

iv)
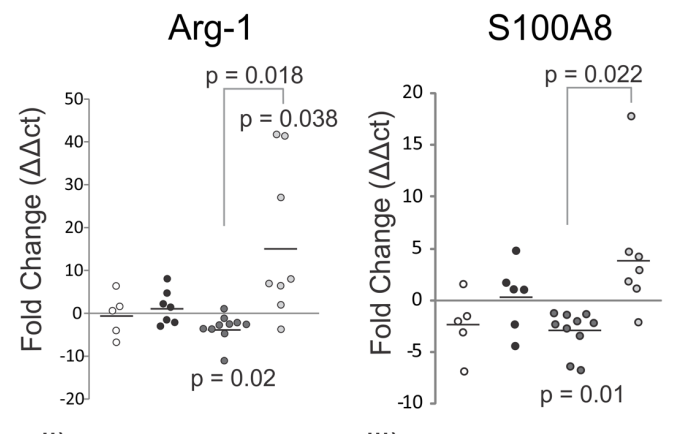

viii)

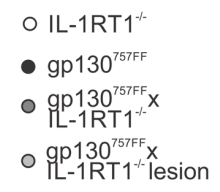

vii)

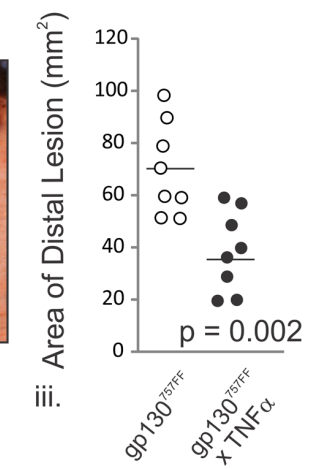

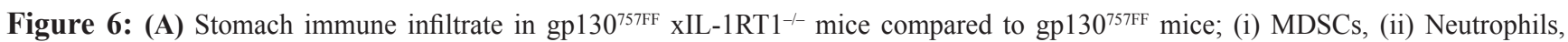
(iii) Macrophages, (iv) $\mathrm{CD}^{+} \mathrm{T}$ cells and (v) $\mathrm{CD} 8^{+} \mathrm{T}$ cells. (B) Proximal stomach mRNA expression of immune modulating genes in gp130 $0^{757 F F}$ xIL-1RT1-/ cohort mice; (i) IL-1 $\alpha$ (ii) IL-1 $\beta$ (iii) MIP2 (iv) TNF $\alpha$ (v) IL-23 (vi) Amphiregulin (vii) Arg-1 (viii) S100A8 \& (ix) S100A9. (C) (i-iii) Assessment of distal tumor size in gp130 $0^{757 \mathrm{FF}} \times \mathrm{xNNF}^{-/}$mice compared to gp130757FF mice. $p$-values are as indicated for statistically significant changes $(p<0.05)$. 
MIP2 and TNF- $\alpha$ mRNA expression were substantially increased in gp130 $137 \mathrm{FF}$ xIL-1RT1 $1^{-/}$cardiac lesions compared to unaffected gp $130^{757 \mathrm{FF}} \mathrm{xIL}-1 \mathrm{RT} 1^{-/}$proximal stomach $(4.5 \pm 1.0$ and $5.3 \pm 2.2$ fold respectively; Fig. 6Biii\&iv). IL-23 and amphiregulin expression were also significantly increased in gp $130^{\mathrm{FF}} \times \mathrm{XIL}-1 \mathrm{RT} 1^{-/}$cardiac lesions compared to unaffected stomach $(1.8 \pm 0.8$ and $4.2 \pm 1.6$ fold respectively; Fig. $6 \mathrm{Bv} \& v i)$. Additionally, as we have demonstrated increase MDSC populations in the gp130 ${ }^{757 F F}$ xIL-1RT1 ${ }^{-/}$stomach and TNF- $\alpha$ can directly influence MDSC recruitment [28] we measured the expression of Arg-1, S100A8 and S100A9, genes associated with MDSC development and function. In unaffected proximal stomach of gp $130^{757 \mathrm{FF}} \mathrm{xIL}-1 \mathrm{RT} 1^{-/}$mice Arg-1, S100A8\&9 were decreased compared to wildtype ( -3.3 $\pm 1.0,-3.0 \pm 0.6$ and $-2.3 \pm 0.3$ fold respectively; Fig. 6Bvii, vii\&ix), however all were markedly increased in gp130 ${ }^{\mathrm{FF}}$ xIL-1RT1 ${ }^{-/}$cardiac lesions $(16.3 \pm 6.3,4.4 \pm 2.3$ and $5.0 \pm 2.8$ fold respectively; Fig. 6Bvii, vii\&ix). These data suggest that TNF- $\alpha$ expression in the cardiac lesions of gp $130^{757 \mathrm{FF}} \mathrm{xIL}-1 \mathrm{RT}^{-1-}$ results in an increase in MDSC recruitment.

To further assessed the effects of TNF- $\alpha$ on the gp130 ${ }^{757 F F}$ gastric tumor phenotype, gp $130^{757 F F}$ mice were crossed with $\mathrm{TNF}-\alpha^{-/}$mice. Macroscopic assessment of lesion size demonstrated that gp $130^{757 F F} \times \mathrm{xNF}-\alpha^{-1-}$ mice had considerably smaller distal tumors compared to $\mathrm{gp} 130^{\mathrm{FF}}$ mice $\left(38.91 \pm 5.46\right.$ and $70.16 \pm 6.27 \mathrm{~mm}^{2}$ respectively; Fig. $6 \mathrm{Bi}-\mathrm{iii})$. These data show that TNF- $\alpha$ promotes gp130 $157 \mathrm{FF}$ tumor development, potentially through the recruitment of MDSCs that are able to restrict the anti-tumor response and are thus permissive for tumor growth.

\section{DISCUSSION}

IL- $1 \alpha$ and IL-1 $\beta$ mRNA expression is upregulated in antral tumors of gp $130^{757 F F}$ mice, consistent with the view that IL-1RT1 ligands may contribute to the development of gastric antral tumors in this STAT3-dependent model, and may serve as novel therapeutic targets for gastric cancer. To test this directly gp $130^{757 F F}$ mice were crossed with IL-1RT1 ${ }^{-1-}$ mice. Unexpectedly, in the absence of IL-1RT1 signaling there was a significant increase in the size of gp $130^{757 \mathrm{FF}}$ gastric antral tumors, demonstrating that not only is activation of IL-1 signaling dispensable for tumorigenesis in the distal stomach of gp $130^{757 \mathrm{FF}}$ mice, but that patent IL-1 signaling pathways can act to restrict tumor growth in the presence of cytokine-driven STAT3mediated gene transcription.

The negative influence of IL-1RT1 signaling was also observed in the gp $130^{757 \mathrm{FF}} \mathrm{xIL}-1 \mathrm{RT} 1^{-/}$proximal stomach where a significant increase in both tumor incidence and size compared to gp $130^{757 F F}$ mice was observed. These proximal tumors originated from the gastric cardia at the limiting ridge near the gastro-esophageal and fore-stomach junction. gp130 $757 \mathrm{FF}$ xIL-1RT1 $1^{-/}$cardiac lesions were associated with elevated STAT3 activation, a modulated immune response, including an enrichment of MDSCs, and loss of specialized gastric cells. The clear positive correlation between STAT3 activation and cardiac lesions indicates that STAT3 activation is causative for cardiac tumor development in this model. Furthermore, increased STAT3 activation correlated with increased IL-11 but not IL-6 mRNA expression, suggesting that IL-11 is the main ligand driving gp130 activation in cardiac lesions, as we have previously demonstrated for the primary antral lesions in the gp130 $157 \mathrm{FF}$ mouse model [19]. Additionally, at this advanced stage of pathology the recruitment of immunocytes which express STAT3 inducing genes may also contribute to STAT3 activation. This alternative pathway is supported by our analysis of the mRNA expression of IL-23 and amphiregulin, both of which signal via STAT3 $[29,30]$ and which were increased in gp130757FF $x$ IL-1RT1 ${ }^{-/}$cardiac lesions. Nonetheless, IL-11 is absolutely required for gp $130^{757 \mathrm{FF}}$ gastric tumorigenesis and therefore must be considered the primary initiator of cardiac lesions.

The role of IL-1RT1 signaling during IL-11induced STAT3 activation without tumor inducing gp130 mutations was also assessed. This was achieved by continuous, systemic, low dose IL-11 administration. IL-1RT1 ${ }^{-/}$mice treated with IL-11 showed immune and gastric cell marker changes similar to those observed in gp $130^{757 F F} \times I L-1 \mathrm{RT}^{-/-}$cardiac lesions, whereas wildtype mice treated with IL-11 did not. This demonstrates that IL-11 can promote gastric atrophy, consistent with our previous findings [7] and that IL-1 signaling antagonizes IL-11-dependent tumorigenesis.

Both wildtype and IL-1RT1 $1^{-/}$mice treated with IL-11 had increased STAT3 activation in the proximal stomach and unchanged endogenous IL-11 expression. IL-6 expression on the other hand, was markedly reduced in $\mathrm{IL}_{-1 \mathrm{RT}^{-/}}$mice administered IL-11, suggesting that IL-6 expression is dependent on intact IL-1RT1 signaling. Quante et al (2012) [4] suggest that enhanced IL-6-induced STAT3 activation is crucial for the cardiac/ esophageal pathology that develops in IL- $1 \beta$ transgenic mice. However they did not measure IL-11 expression, a well-documented inducer of STAT3 phosphorylation whose expression is absolutely required in the gp $130^{757 \mathrm{FF}}$ mouse [19] and is strongly upregulated in several other models of gastric tumorigenesis [19], including the cardiac lesions in gp $130^{757 \mathrm{FF}} \mathrm{xIL}-1 \mathrm{RT} 1^{-/-}$mice.

In general we observed the same cardiac pathology and gene expression pattern in mouse genetic models which have either exaggerated IL-1RT1 signaling [4], or ablated IL-1RT1 signaling (gp130757FF $\mathrm{xIL}-1 \mathrm{RT} 1^{-/-}$). Therefore it seems that the common thread that links the cardiac pathology in both models is not intact IL-1RT1 signaling per se, but augmented expression of IL-6 family cytokines which hyperactivate gp130/STAT3 leading to 
MDSC recruitment. Together these outcomes highlight the importance of gp130 ligands and dysfunctional IL1RT1 cytokines in driving upper gastric pathology. Supporting evidence comes from individuals carrying polymorphisms in the IL- $1 \alpha$, IL- $1 \beta$ and IL-1RN gene cluster that lead to elevated expression of IL-1 cytokines, and who are actually protected from gastro-eosphageal reflux disease and Barrett's esophagitis [31-33], suggesting that a delicate balance is at play, with expression of IL-1 cytokines in the proximal stomach and esophagus under some circumstances leading to pathology, and in others being protective. These findings in conjunction with the observed detrimental effects of ablated IL-1 signaling in IL-11/STAT3 mediated gastric pathology demonstrated here, suggest that IL-1 receptor blockade, or immunoneutralisation of ligands may not be suitable targets for preventing gastric cancer progression. Furthermore inhibiting these cytokines in humans may result in more aggressive tumors and possibly enhanced metastasis.

The observation that loss of IL-1RT1 signaling in the gp $130^{757 \mathrm{FF}}$ mouse produces more pathology was unexpected considering that high expressing IL-1 $\beta$ polymorphic variants correlate with increased gastric cancer risk in Caucasians, and transgenic overexpression of IL-1 $\beta$ in mice results in severe gastric and esophageal pathology $[4,8]$. However, while much of the current literature has focused on the pro-tumorigenic effects of IL-1 $\beta$, particularly in gastric cancer, IL- $1 \alpha$, which was preferentially expressed in gp $130^{757 \mathrm{FF}} \mathrm{xIL}-1 \mathrm{RT} 1^{-/}$cardiac lesions at the expense of IL- $1 \beta$, has been poorly studied in comparison. Although these two cytokines share many functions, IL- $1 \alpha$ has a novel role as an alarmin. Alarmins describe a class of multifunctional cytokines released by necrotic cells in response to infection or injury to promote an immune responses [34]. As such, IL-1 $\alpha$ is expressed constitutively in the nuclei of cells to be released and activated by cellular damage, thereby initiating an immediate inflammatory response $[15,35,36]$. In mice, the loss of IL- $1 \alpha$, but not IL- $1 \beta$, results in decreased survival rates in response to lethal endotoxemia [37], and impaired immune function during infection [38-40]. Furthermore, the loss of IL-1 signaling in colitis in mice results in more severe colonic pathology suggesting IL-1 has the capacity to protect against mucosal injury [41, 42]. Many studies identify IL- $1 \alpha$ as being a critical component of the early phase recruitment of immunocytes particularly macrophages and neutrophils [43-45]. We suggest that in our model the absence of patent IL-1 $\alpha$ alarmin function in the stomach due to IL-1RT1 deletion results in inappropriate activation of cellular infiltrate, ultimately resulting in chronic damage, and enhanced tumorigenesis.

The current dogma supports the view that IL-1 $\beta$ promotes enrichment of MDSCs in the stomach thus balancing the alarmin activity of IL-1 $\alpha$ [46], and can lead to gastric tumour formation [8]. Additionally, MDSC numbers are known to be an independent risk factor for disease progression in gastric and esophageal cancer [47, 48]. MDSCs can promote tumor immune tolerance through suppression of $\mathrm{T}$ cell responses leading to tumor expansion and disease progression $[49,50]$. In the gastrointestinal tract, MDSC-induced tumor immune tolerance has been demonstrated to promote gastric and esophageal cancers $[4,8,47,48]$, suggesting that enrichment of MDSCs directly correlates to gastric and esophageal disease outcomes. Here, we demonstrate that IL-11/STAT3 causes an enrichment of MDSCs independent of IL-RT1 signaling. This finding is consistent with published data from the lung and pancreas [51, 52]. Furthermore, IL-6 signaling, a potent STAT3 inducer, is required for IL-1 $\beta$ induced gastric and esophageal pathology $[4,8]$, indicating that STAT3 signaling is necessary for MDSC expansion and explains how both overexpression and ablated IL-1 signaling can induce cardiac pathology through STAT3 dependent MDSC enrichment.

An additional consequence of a deficiency in IL1RT1 signaling in the gp130 $157 \mathrm{FF}$ stomach is elevated TNF $\alpha$, also known to promote the enrichment of MDSC populations though expression of S100A8 and S100A9 [52]. One mechanism by which MDSCs may promote tumor growth is through expression of arginase-1, which in turn diminishes $\mathrm{T}$ cell mediated anti-tumor responses [48]. Here we show elevated S100A8 and 9 as well as arginase-1, suggesting enhanced MDSC activity in stomach tumors deficient in IL-1RT1 signaling. Moreover the absence of TNF $\alpha$ in gp $130^{757 F F}$ mice results in smaller tumors, likely as a result of reduced numbers of MDSCs and an exaggerated pro-inflammatory environment.

Here we have demonstrated that IL-1RT1 $1^{-/-}$ signaling is not required for IL-11/STAT3 mediated pathology, with genetic depletion of IL-1RT1 $1^{-/}$resulting in a more severe tumor phenotype by promoting an antiinflammatory, pro-tumorigenic environment. We propose a mechanism involving IL-11-dependent recruitment of tumor promoting MDSCs to the stomach. Furthermore, these data provide additional evidence that gp130-induced STAT3 activation is required for cardiac and esophageal pathology, and may provide the basis for as a future therapeutic target for such pathologies.

\section{MATERIALS AND METHODS}

\section{Mice}

All mice were on a $\mathrm{C} 57 \mathrm{Bl} / 6$ background and were used at 12-14 weeks of age. Transgenic mice were genotyped by multiplex PCR as previously described [7, 20]. Ethical approval (\#664A) was obtained from the animal ethics committee of the Murdoch Children's Research Institute. 


\section{Cytokine treatment}

WT mice and IL-1RT1 mice $(n>10)$ were systemically administered $1 \mu \mathrm{g}$ of recombinant human IL-11 protein (Shenandoah) per day for seven days, or saline, via Mini Osmotic Pumps (MOP) (Alzet Model 1007D) implanted subcutaneously.

\section{Tissue preparation}

Mouse stomachs were prepared and analysed as previously described [21]. Briefly, the stomach was bisected, antrum and fundus from one half were frozen for TRIzol extraction, and the other half fixed in $4 \%$ paraformaldehyde in PBS. When obvious proximal (cardiac) stomach lesions were evident, the proximal stomach was further divided into affected and unaffected tissues. Spleens were also collected from MOP mice; one half was frozen for TRIzol extraction and the other fixed in $4 \%$ paraformaldehyde in PBS.

\section{Macrophage isolation and analysis}

To harvest peritoneal macrophages, $5 \mathrm{~mL}$ of HBSS (Sigma) containing 10 units $/ \mathrm{mL}$ of heparin (Sigma) was injected into the peritoneal cavity ( $n=5 /$ group). Extracted cells were harvested, washed, and resuspended in complete RPMI then plated onto 6-well culture plates. Plates were incubated at $37^{\circ} \mathrm{C}$ for 10 minutes to allow macrophages to adhere. Cultures were then washed to remove nonmacrophage cells. Macrophages were incubated overnight at $37^{\circ} \mathrm{C}$. The next day, macrophage cultures were treated with either saline or $100 \mathrm{ng} \mathrm{LPS} / \mathrm{mL}$ in fresh media. Cells were harvest using TRIzol reagent (Life Technologies).

\section{Quantitative RT-PCR}

RNA was harvested using TRIzol reagent (Life Technologies). RNA ( $3 \mu \mathrm{g})(n \geq 10$ animals/group) was reverse transcribed using Moloney murine leukemia virus reverse transcriptase (Promega) primed with oligo (dT). Quantitative RT-PCR (QRTPCR) primers were designed using PRIMER EXPRESS (Applied Biosystems) (Supplementary Table 1). SYBR green chemistry was used with $\mathrm{rL} 32$ as the internal reference gene. QRTPCR conditions were $95^{\circ} \mathrm{C}$ for $10 \mathrm{~min}, 40$ cycles of $95^{\circ} \mathrm{C}$ for $15 \mathrm{sec}$ and $60^{\circ} \mathrm{C}$ for $15 \mathrm{sec}$ (Applied Biosystems AB7500). Results were analyzed using sequence detector software, relative fold differences were determined using the $\Delta \Delta \mathrm{Ct}$ method.

\section{Immunoblotting}

Proteins ( $n \geq 10$ animals/group) were prepared using TRIzol (Life Technologies) and $20 \mu \mathrm{g}$ of extract was subjected to SDS PAGE. Membranes were incubated with specific antibodies (Supplementary Table 2), peroxideconjugated secondary antibody and visualized by enhanced chemiluminescence (Amersham). Quantification was done using Quantity 1 software (Bio-Rad Laboratories) and ratios of phosphorylated: total protein determined from duplicate membranes.

\section{IL-1 $\beta$ ELISA assay}

TRIzol extracted proteins were diluted to $0.1 \%$ SDS using sterile PBS and IL- $1 \beta$ sandwich ELISA was performed as previously described $[53,54]$.

\section{Quantitative morphometry}

Macroscopic: Images were captured on a Coolpix 4500 digital camera (Nikon Instruments, Melville, NY). Quantitative analysis of stomach lesions was done using ImageJ software for Windows v1.38 [55]. Measurements were converted to millimetres after comparison with a calibrated graticule.

Microscopic: Images of $\mathrm{H} \& \mathrm{E}$ stomachs were taken along the length of the stomach using a Coolpix 4500 digital camera attached to a light microscope. Lengths and areas were manually traced on these images using ImageJ software (see above). Measurements were converted to millimetres after comparison with a calibrated graticule.

\section{Cell isolation and flow cytometry (FACS) analysis}

Stomach cell isolation: Stomachs were collected in HBSS (2mM EDTA, 2\% FBS) then perfused with digestion media (1x HBSS [without calcium and magnesium], 5mM EDTA, 5\% FBS and $1 \mathrm{mM}$ dithiothreitol [DTT]) and incubated at $37^{\circ} \mathrm{C}$ for 15 minutes. Stomachs were then cut and incubated in digestion media for a further 15 minutes then passed through a $70 \mu \mathrm{m}$ cell strainer. Cell suspensions were stained with fluorescently labeled antibodies (Supplementary Table 3) in HBSS (2mM EDTA, 2\% FBS), washed and resuspended in HBSS for FACS analysis (Becton Dicknson LSRII and FACSDiva v6.1.1) or cell sorting (BD Influx cell sorter).

Spleen cell isolation: One third of the spleen was made into a single cell suspension. Red blood cells were lysed with Ammonium-Tris Chloride buffer for 5 minutes at room temperature. Cell suspensions were stained with fluorescently labeled antibodies similar to that of the stomach.

FACS analysis: Dead, autofluorescent and aggregated cells were gated out of on the basis of FSC, SSC and propidium iodide staining. Live cells were gated based on FSC v SSC plot and the number of events was recorded for the different cell types (Supplementary Table 3). The number of events for each cell type was compared to the total number of all live cell events and proportions of cell types were compared between treatment groups. 


\section{Statistical analysis}

All data were expressed as mean \pm SEM and statistical analysis was performed by one-way analysis of variance (ANOVA) and the appropriate parametric or nonparametric statistical test using Sigmastat (Jandel Scientific). All $p$ values were derived and comparison was performed between the wildtype control group and specific treatment groups unless indicated. $p$ values $\leq 0.05$ were considered statistically significant.

\section{ACKNOWLEDGMENTS}

None

\section{Funding}

Victorian Government's Operational Infrastructure Support Program and NH\&MRC Australia \#APP1006688

\section{Conflict of interest}

The authors declare no conflicts of interest.

\section{Editorial note}

This paper has been accepted based in part on peerreview conducted by another journal and the authors' response and revisions as well as expedited peer-review in Oncotarget.

\section{REFERENCES}

1. Lauren P. The Two Histological Main Types of Gastric Carcinoma: Diffuse and So-Called Intestinal-Type Carcinoma. An Attempt at a Histo-Clinical Classification. Acta pathologica et microbiologica Scandinavica. 1965; 64:31-49.

2. Correa P, Houghton J. Carcinogenesis of Helicobacter pylori. Gastroenterology. 2007; 133:659-672.

3. Stojsic ZM, Stevanovic RM, Stojanovic MM, Stanojevic AD, Bacetic DT. Histological features of gastric cardia in adults: an autopsy study. Journal of gastrointestinal and liver diseases: JGLD. 2011; 20:13-18.

4. Quante M, Bhagat G, Abrams JA, Marache F, Good P, Lee MD, Lee Y, Friedman R, Asfaha S, Dubeykovskaya Z, Mahmood U, Figueiredo JL, Kitajewski J, Shawber C, Lightdale CJ, Rustgi AK, et al. Bile acid and inflammation activate gastric cardia stem cells in a mouse model of Barrett-like metaplasia. Cancer cell. 2012; 21:36-51.

5. Abrams JA, Gonsalves L, Neugut AI. Diverging trends in the incidence of reflux-related and Helicobacter pylorirelated gastric cardia cancer. Journal of clinical gastroenterology. 2013; 47:322-327.
6. Lagergren J, Mattsson F. Diverging trends in recent population-based survival rates in oesophageal and gastric cancer. PloS one. 2012; 7:e41352.

7. Howlett M, Chalinor HV, Buzzelli JN, Nguyen N, van Driel IR, Bell KM, Fox JG, Dimitriadis E, Menheniott TR, Giraud AS, Judd LM. IL-11 is a parietal cell cytokine that induces atrophic gastritis. Gut. 2012; 61:1398-1409.

8. Tu S, Bhagat G, Cui G, Takaishi S, Kurt-Jones EA, Rickman B, Betz KS, Penz-Oesterreicher M, Bjorkdahl O, Fox JG, Wang TC. Overexpression of interleukin-1beta induces gastric inflammation and cancer and mobilizes myeloid-derived suppressor cells in mice. Cancer cell. 2008; 14:408-419.

9. Barbera M, Fitzgerald RC. Cellular origin of Barrett's metaplasia and oesophageal stem cells. Biochemical Society transactions. 2010; 38:370-373.

10. El-Omar EM, Carrington $\mathrm{M}$, Chow WH, McColl KE, Bream JH, Young HA, Herrera J, Lissowska J, Yuan CC, Rothman N, Lanyon G, Martin M, Fraumeni JF Jr, Rabkin CS. The role of interleukin-1 polymorphisms in the pathogenesis of gastric cancer. Nature. 2001; 412:99.

11. Chen MF, Lu MS, Chen PT, Chen WC, Lin PY, Lee KD. Role of interleukin 1 beta in esophageal squamous cell carcinoma. Journal of molecular medicine. 2012; 90:89-100.

12. Huang Q, Lan F, Wang X, Yu Y, Ouyang X, Zheng F, Han J, Lin Y, Xie Y, Xie F, Liu W, Yang X, Wang H, Dong L, Wang L, Tan J. IL-1beta-induced activation of p38 promotes metastasis in gastric adenocarcinoma via upregulation of AP-1/c-fos, MMP2 and MMP9. Molecular cancer. $2014 ; 13: 18$.

13. Dinarello CA. Interleukin-1 in the pathogenesis and treatment of inflammatory diseases. Blood. 2011; 117:3720-3732.

14. Arend WP, Palmer G, Gabay C. IL-1, IL-18, and IL-33 families of cytokines. Immunological reviews. 2008; 223:20-38.

15. Cohen I, Rider P, Carmi Y, Braiman A, Dotan S, White MR, Voronov E, Martin MU, Dinarello CA, Apte RN. Differential release of chromatin-bound IL-1alpha discriminates between necrotic and apoptotic cell death by the ability to induce sterile inflammation. Proceedings of the National Academy of Sciences of the United States of America. 2010; 107:2574-2579.

16. Ando $\mathrm{T}$, Kusugami $\mathrm{K}$, Ohsuga $\mathrm{M}$, Ina $\mathrm{K}$, Ichiyama $\mathrm{S}$, Nada T, Ohta M. Mucosal macrophage inflammatory protein-alpha levels are increased in Helicobacter pylori infection. Journal of clinical gastroenterology. 1998; 27:S144-149.

17. Tomimatsu S, Ichikura T, Mochizuki H. Significant correlation between expression of interleukin-1alpha and liver metastasis in gastric carcinoma. Cancer. 2001; 91:1272-1276. 
18. Ernst M, Najdovska M, Grail D, Lundgren-May T, Buchert M, Tye H, Matthews VB, Armes J, Bhathal PS, Hughes NR, Marcusson EG, Karras JG, Na S, Sedgwick JD, Hertzog PJ, Jenkins BJ. STAT3 and STAT1 mediate IL-11-dependent and inflammation-associated gastric tumorigenesis in gp130 receptor mutant mice. The Journal of clinical investigation. 2008; 118:1727-1738.

19. Howlett M, Giraud AS, Lescesen H, Jackson CB, Kalantzis A, Van Driel IR, Robb L, Van der Hoek M, Ernst M, Minamoto T, Boussioutas A, Oshima H, Oshima M, Judd LM. The interleukin-6 family cytokine interleukin-11 regulates homeostatic epithelial cell turnover and promotes gastric tumor development. Gastroenterology. 2009; 136:967-977.

20. Judd LM, Alderman BM, Howlett M, Shulkes A, Dow C, Moverley J, Grail D, Jenkins BJ, Ernst M, Giraud AS. Gastric cancer development in mice lacking the SHP2 binding site on the IL-6 family co-receptor gp 130 . Gastroenterology. 2004; 126:196-207.

21. Tebbutt NC, Giraud AS, Inglese M, Jenkins B, Waring P, Clay FJ, Malki S, Alderman BM, Grail D, Hollande F, Heath JK, Ernst M. Reciprocal regulation of gastrointestinal homeostasis by SHP2 and STAT-mediated trefoil gene activation in gp130 mutant mice. Nature medicine. 2002; 8:1089-1097.

22. Jackson CB, Giraud AS. STAT3 as a prognostic marker in human gastric cancer. Journal of gastroenterology and hepatology. 2009; 24:505-507.

23. Lawrence T, Natoli G. Transcriptional regulation of macrophage polarization: enabling diversity with identity. Nature reviews Immunology. 2011; 11:750-761.

24. Hirano T, Nakajima K, Hibi M. Signaling mechanisms through gp130: a model of the cytokine system. Cytokine \& growth factor reviews. 1997; 8:241-252.

25. Kang W, Reid KB. DMBT1, a regulator of mucosal homeostasis through the linking of mucosal defense and regeneration?. FEBS letters. 2003; 540:21-25.

26. Miki T, Holst O, Hardt WD. The bactericidal activity of the C-type lectin RegIIIbeta against Gram-negative bacteria involves binding to lipid A. The Journal of biological chemistry. 2012; 287:34844-34855.

27. Menheniott TR, Kurklu B, Giraud AS. Gastrokines: stomach-specific proteins with putative homeostatic and tumor suppressor roles. American journal of physiology Gastrointestinal and liver physiology. 2013; 304:G109-121.

28. Youn JI, Nagaraj S, Collazo M, Gabrilovich DI. Subsets of myeloid-derived suppressor cells in tumor-bearing mice. Journal of immunology. 2008; 181:5791-5802.

29. Hsu YL, Huang MS, Cheng DE, Hung JY, Yang CJ, Chou $\mathrm{SH}$, Kuo PL. Lung tumor-associated dendritic cell-derived amphiregulin increased cancer progression. Journal of immunology. 2011; 187:1733-1744.
30. Lankford CS, Frucht DM. A unique role for IL-23 in promoting cellular immunity. Journal of leukocyte biology. 2003; 73:49-56.

31. Ando T, El-Omar EM, Goto Y, Nobata K, Watanabe O, Maeda O, Ishiguro K, Minami M, Hamajima N, Goto H. Interleukin $1 \mathrm{~B}$ proinflammatory genotypes protect against gastro-oesophageal reflux disease through induction of corpus atrophy. Gut. 2006; 55:158-164.

32. Izakovicova Holla L, Borilova Linhartova P, Hrdlickova B, Marek F, Dolina J, Rihak V, Kala Z. Haplotypes of the IL-1 gene cluster are associated with gastroesophageal reflux disease and Barrett's esophagus. Human immunology. 2013; 74:1161-1169.

33. Queiroz DM, Guerra JB, Rocha GA, Rocha AM, Santos A, De Oliveira AG, Cabral MM, Nogueira AM, De Oliveira CA. IL1B and IL1RN polymorphic genes and Helicobacter pylori cagA strains decrease the risk of reflux esophagitis. Gastroenterology. 2004; 127:73-79.

34. Oppenheim JJ, Yang D. Alarmins: chemotactic activators of immune responses. Current opinion in immunology. 2005; 17:359-365.

35. Rider P, Kaplanov I, Romzova M, Bernardis L, Braiman A, Voronov E, Apte RN. The transcription of the alarmin cytokine interleukin-1 alpha is controlled by hypoxia inducible factors 1 and 2 alpha in hypoxic cells. Frontiers in immunology. 2012; 3:290.

36. Tracy EC, Bowman MJ, Henderson BW, Baumann H. Interleukin-1alpha is the major alarmin of lung epithelial cells released during photodynamic therapy to induce inflammatory mediators in fibroblasts. British journal of cancer. 2012; 107:1534-1546.

37. Joosten LA, Van De Veerdonk FL, Vonk AG, Boerman OC, Keuter M, Fantuzzi G, Verschueren I, Van Der Poll T, Dinarello CA, Kullberg BJ, Van Der Meer JW, Netea MG. Differential susceptibility to lethal endotoxaemia in mice deficient in IL-1alpha, IL-1beta or IL-1 receptor type I. APMIS : acta pathologica, microbiologica, et immunologica Scandinavica. 2010; 118:1000-1007.

38. Labow M, Shuster D, Zetterstrom M, Nunes P, Terry R, Cullinan EB, Bartfai T, Solorzano C, Moldawer LL, Chizzonite R, McIntyre KW. Absence of IL-1 signaling and reduced inflammatory response in IL-1 type I receptor-deficient mice. Journal of immunology. 1997; 159:2452-2461.

39. Lebeis SL, Powell KR, Merlin D, Sherman MA, Kalman D. Interleukin-1 receptor signaling protects mice from lethal intestinal damage caused by the attaching and effacing pathogen Citrobacter rodentium. Infection and immunity. 2009; 77:604-614.

40. Wieland CW, Florquin S, Pater JM, Weijer S, van der Poll T. Interleukin-1 contributes to an effective clearance of Mycobacterium kansasii from the respiratory tract. Microbes and infection/Institut Pasteur. 2006; 8:2409-2413. 
41. Gonzalez-Navajas JM, Law J, Nguyen KP, Bhargava M, Corr MP, Varki N, Eckmann L, Hoffman HM, Lee J, Raz E. Interleukin 1 receptor signaling regulates DUBA expression and facilitates Toll-like receptor 9-driven antiinflammatory cytokine production. The Journal of experimental medicine. 2010; 207:2799-2807.

42. Kojouharoff G, Hans W, Obermeier F, Mannel DN, Andus T, Scholmerich J, Gross V, Falk W. Neutralization of tumour necrosis factor (TNF) but not of IL-1 reduces inflammation in chronic dextran sulphate sodium-induced colitis in mice. Clinical and experimental immunology. 1997; 107:353-358.

43. Kim BS, Jin YH, Meng L, Hou W, Kang HS, Park HS, Koh CS. IL-1 signal affects both protection and pathogenesis of virus-induced chronic CNS demyelinating disease. Journal of neuroinflammation. 2012; 9:217.

44. Lee PY, Kumagai Y, Xu Y, Li Y, Barker T, Liu C, Sobel ES, Takeuchi O, Akira S, Satoh M, Reeves WH. IL-1alpha modulates neutrophil recruitment in chronic inflammation induced by hydrocarbon oil. Journal of immunology. 2011; 186:1747-1754.

45. Ueda Y, Cain DW, Kuraoka M, Kondo M, Kelsoe G. IL-1R type I-dependent hemopoietic stem cell proliferation is necessary for inflammatory granulopoiesis and reactive neutrophilia. Journal of immunology. 2009; 182:6477-6484.

46. Voronov E, Dotan S, Krelin Y, Song X, Elkabets M, Carmi Y, Rider P, Idan C, Romzova M, Kaplanov I, Apte RN. Unique Versus Redundant Functions of IL-1alpha and IL-1beta in the Tumor Microenvironment. Frontiers in immunology. 2013; 4:177.

47. Gabitass RF, Annels NE, Stocken DD, Pandha HA, Middleton GW. Elevated myeloid-derived suppressor cells in pancreatic, esophageal and gastric cancer are an independent prognostic factor and are associated with significant elevation of the Th2 cytokine interleukin-13. Cancer immunology, immunotherapy: CII. 2011; 60:1419-1430.

48. Raber P, Ochoa AC, Rodriguez PC. Metabolism of L-arginine by myeloid-derived suppressor cells in cancer: mechanisms of $\mathrm{T}$ cell suppression and therapeutic perspectives. Immunological investigations. 2012; 41:614-634.

49. Ryzhov S, Novitskiy SV, Goldstein AE, Biktasova A, Blackburn MR, Biaggioni I, Dikov MM, Feoktistov I. Adenosinergic regulation of the expansion and immunosuppressive activity of CD11b+Gr1+ cells. Journal of immunology. 2011; 187:6120-6129.

50. Zhu K, Zhang N, Guo N, Yang J, Wang J, Yang C, Yang C, Zhu L, Xu C, Deng Q, Zhu R, Wang H, Chen X, Shi Y, Li Y, Leng Q. SSC(high)CD11b(high)Ly-6C(high) Ly-6G(low) myeloid cells curtail CD4 $\mathrm{T}$ cell response by inducible nitric oxide synthase in murine hepatitis. The international journal of biochemistry \& cell biology. 2014; 54:89-97.

51. Mace TA, Ameen Z, Collins A, Wojcik S, Mair M, Young GS, Fuchs JR, Eubank TD, Frankel WL, Bekaii-Saab T, Bloomston M, Lesinski GB. Pancreatic cancer-associated stellate cells promote differentiation of myeloid-derived suppressor cells in a STAT3-dependent manner. Cancer research. 2013; 73:3007-3018.

52. Sade-Feldman M, Kanterman J, Ish-Shalom E, Elnekave M, Horwitz E, Baniyash M. Tumor necrosis factor-alpha blocks differentiation and enhances suppressive activity of immature myeloid cells during chronic inflammation. Immunity. 2013; 38:541-554.

53. Chionh YT, Ng GZ, Ong L, Arulmuruganar A, Stent A, Saeed MA, Wee JL, Sutton P. Protease-activated receptor 1 suppresses Helicobacter pylori gastritis via the inhibition of macrophage cytokine secretion and interferon regulatory factor 5. Mucosal Immunology advance online publication. 28 May 2014; doi:10.1038/mi.2014.43 (citation from Pubmed).

54. Ng GZ, Chionh YT, Sutton P. Vaccine-mediated protection against Helicobacter pylori is not associated with increased salivary cytokine or mucin expression. Helicobacter. 2014; 19:48-54.

55. Schneider CA, Rasband WS, Eliceiri KW. NIH Image to ImageJ: 25 years of image analysis. Nature methods. 2012; 9:671-675. 